\title{
Metal Species in Biology: Bottom-Up and Top-Down LC Approaches in Applied Toxicological Research
}

\author{
Jürgen Gailer \\ Department of Chemistry, University of Calgary, 2500 University Drive NW, Calgary, AB, Canada T2N 1N4 \\ Correspondence should be addressed to Jürgen Gailer; jgailer@ucalgary.ca
}

Received 30 January 2013; Accepted 19 February 2013

Academic Editors: B. K. Mandal, A. Namera, Y. Qiu, and A. I. Suarez

Copyright (C) 2013 Jürgen Gailer. This is an open access article distributed under the Creative Commons Attribution License, which permits unrestricted use, distribution, and reproduction in any medium, provided the original work is properly cited.

\begin{abstract}
Since the inception of liquid chromatography (LC) more than 100 years ago this separation technique has been developed into a powerful analytical tool that is frequently applied in life science research. To this end, unique insights into the interaction of metal species (throughout this manuscript "metal species" refers to "toxic metals, metalloid compounds, and metal-based drugs" and "toxic metals" to "toxic metals and metalloid compounds") with endogenous ligands can be obtained by using LC approaches that involve their hyphenation with inductively coupled plasma-based element specific detectors. This review aims to provide a synopsis of the different LC approaches which may be employed to advance our understanding of these interactions either in a "bottom-up" or a "top-down" manner. In the "bottom-up" LC-configuration, endogenous ligands are introduced into a physiologically relevant mobile phase buffer, and the metal species of interest is injected. Subsequent "interrogation" of the on-column formed complex(es) by employing a suitable separation mechanism (e.g., size exclusion chromatography or reversed-phase LC) while changing the ligand concentration(s), the column temperature or the $\mathrm{pH}$ can provide valuable insight into the formation of complexes under near physiological conditions. This approach allows to establish the relative stability and hydrophobicity of metal-ligand complexes as well as the dynamic coordination of a metal species (injected) to two ligands (dissolved in the mobile phase). Conversely, the "top-down" analysis of a biological fluid (e.g., blood plasma) by LC (e.g., using size exclusion chromatography) can be used to determine the size distribution of endogenous metalloproteins which are collectively referred to as the "metalloproteome". This approach can provide unique insight into the metabolism and the plasma protein binding of metal species, and can simultaneously visualize the dose-dependent perturbation of the metalloproteome by a particular metal species. The concerted application of these LC approaches is destined to provide new insight into biochemical processes which represent an important starting point to advance human health in the 21st century.
\end{abstract}

\section{Introduction}

Based on his work on plant pigments, M.S. Tswett serendipitously invented adsorption chromatography as a universal analytical method to separate chemical compounds in 1906 [1]. After an interregnum of $\sim 40$ years, the discovery of liquidliquid partition chromatography by A.J.P. Martin and R.L.M. Synge breathed new life into this ground-breaking separation approach [2] and was-together with the development of the first general theory of chromatography-awarded the Nobel Prize in Chemistry in 1952 [3]. Over the intervening years, liquid chromatography (LC) has matured into one of the most enabling and widely used separation technologies in modern analytical chemistry [4]. This evolution has involved the development of stationary phases with progressively smaller particle diameters [5], the miniaturization of column dimensions $[6,7]$ and resulted in the beginning of high performance liquid chromatography (HPLC) in the early 1970s [8]. The need to further increase the column efficiency required the utilization of even smaller particle diameters and culminated in the introduction of ultra performance liquid chromatography (UPLC) in 2004 [9]. In the context of separation science these $\mathrm{LC}$ techniques allowed, for the first time, to analyze complicated biological fluids, such as blood plasma for proteins [10-12] or small molecular weight metabolites $[13,14]$ and put analytical chemists in the unique position to tackle biological complexity. Advances in LC technology have therefore played a pivotal role in setting the stage for modern proteomics [15], metabonomics/metabolomics [1618], and systems biology research [19]. Concomitant with 
these technological developments, a variety of separation mechanisms were established which allowed LC to become an indispensable tool for the purification of active pharmaceutical ingredients (APIs), such as blood coagulation factors from plasma and recombinant proteins from bacterial lysates [20]. Reflecting on this brief historic trajectory of LC and considering the crucial role that this versatile separation technique has served in the context of food analysis and safety [21, 22], it is tempting to equate its significance in contemporary life science research with the role that the microscope plays in biology, the spectroscope has in chemistry, and the Hubble telescope holds in astronomy.

Against this background, it is interesting to note that within the specific research area of "metal species in biology"-loosely defined as the elucidation of health relevant interactions between environmentally abundant toxic metals or metal-based drugs with ligands within organismsapproaches which involve the hyphenation of LC separations with inductively coupled plasma- (ICP-) based detectors [23] have also become more frequently applied over the past 10 years [24]. To understand this trend, one may identify three contributing reasons. The first one is the capability of LC-based approaches to provide fundamentally new insight into the complex interactions between metal species and endogenous ligands in a variety of ways [25-28]. This notion constitutes the main focus of this paper and will be elaborated on in detail later. The second reason is the realization that these interactions provide an important starting point to potentially unravel the mechanisms which link the exposure to certain metal species- unwitting in the context of environmentally abundant toxic metals [29-31] and deliberate with regard to intravenously administered metal-based drugswith adverse human health effects $[32,33]$. Thus, the application of LC-based approaches has potential to provide insight into the etiology of hitherto elusive metal species related disease processes $[34,35]$. The third reason is the inherent ability that LC-based approaches offer in terms of developing more effective antidotes against specific metal species to ultimately advance human health $[36,37]$. As a result, the application of LC-based approaches will likely continue to play an important role in "metal species in biology" research in the years to come. Given that several excellent reviews have detailed either their historic development [38] or various recent methodological advances [24, 27, 28, 39-41], the focus of the present one is to illustrate the different ways in which LC has been employed as a tool to gain insight into the complex interactions that unfold after metal species enter mammalian organism. Furthermore, particular emphasis will be given to studies that have attempted to specifically probe certain aspects of these interactions under near physiological conditions. It is hoped that the presented synopsis may contribute to foster progress toward tackling the by far biggest adversary in the context of revealing the bioinorganic processes which link the exposure of mammals to certain metal species with disease processes: biological complexity [19].

Within the scope of elucidating the role that metals play in health and disease, one may differentiate between three distinguished categories: essential metals/metalloids, toxic metals/metalloids, and pharmacologically active metal compounds/drugs. Owing to the central role that essential metals play in health [42], extensive research has been and continues to be directed toward the elucidation of the exceedingly complex homeostatic regulation mechanisms which maintain their tissue concentrations within a narrow range throughout life [43-49]. Comparatively less, however, is known about the role that environmentally abundant toxic metals may play in the etiology of human disease processes $[34,35,50,51]$, and progress towards the development of more effective chelating agents to efflux these from intoxicated organisms (without harming them) is slow [52]. In a similar vein, the biomolecular basis of the side effects that are associated with clinically used metal-based drugs (and often limit the treatment of patients) remains fragmentary [53-55], and surprisingly little is known about the biochemical mechanism(s) by which so-called "ameliorating agents" mitigate the side-effects of metal-based drugs in patients $[37,56,57]$.

From a conceptual point of view, the effect that any metal species exerts in an organism above a minimum dose and length of exposure-this includes acute toxicity and chronic toxicity-may be investigated by two principle approaches. The traditional "bottom-up" or "reductionistic" approach is based on the isolation of the toxicological problem from the organism followed by in depth studies of the presumed underlying biochemical mechanism(s) using appropriate techniques. For example, to explain why the ingestion of an improperly prepared puffer fish is fatal in $\sim 60 \%$ of the reported poisoning cases (lethal dose in adults: $10 \mu \mathrm{g} / \mathrm{kg}$ body wt), one may want to uncover the molecular mechanism of action of the responsible toxin, tetrodotoxin. To do so, however, one needs to identify first a putative biological target molecule. Since early studies indicated that tetrodotoxin may adversely affect voltage-sensitive $\mathrm{Na}^{+}$channels [58], definitive proof of this hypothesis required detailed studies into the binding of tetrodotoxin to this putative $\mathrm{Na}^{+}$channel protein target [59]. Importantly, this approach can only be employed if some a priori information about a likely molecular mechanism of action (e.g., inhibition of voltagesensitive $\mathrm{Na}^{+}$channels) is available. In contrast, the "topdown" or "systems biology" approach attempts to directly analyze complex biological samples with an appropriate analytical technique to unravel the molecular mechanism of action of a particular toxin therein $[19,60]$. This alternative approach hinges on identifying an analytical technique that is capable of detecting a toxin-induced change in a likely biological compartment (e.g., blood plasma $[26,61]$ ) or to infer that a relevant biotransformation of the toxin of interest has occurred in a particular organ (e.g., the liver) by analyzing an appropriate effluent stream (e.g., bile [62-65]). Importantly, the "top-down" approach offers the advantage that no $a$ priori information about a likely mechanism of toxicity is required and that fundamentally new insights into hitherto unknown mechanisms of action may be obtained. Even though the "bottom-up" approach has been in use longer than the "top-down" approach, the latter is receiving progressively more attention lately. This may be attributed to the fact that organisms are comprised of diverse anatomical structures which maintain intricately intertwined metabolic networks 
<smiles>[NH3+]C(CCC(=O)NC(CS)C(=O)NCC(=O)[O-])C(=O)[O-]</smiles>

(a)<smiles>NC(CCC(=O)NC(CSSCC(NC(=O)CCC([NH3+])C(=O)[O-])C(=O)NCC(=O)[O-])C(=O)NCC(=O)[O-])C(=O)[O-]</smiles>

(e)<smiles>C[N+](C)(C)CC(=O)[O-]</smiles>

(i)

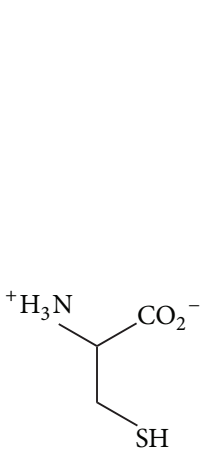

(b)<smiles></smiles>

(c)

(d)<smiles>O=C([O-])CN(CCN(CC(=O)[O-])CC(=O)[O-])CCN(CC(=O)[O-])CC(=O)[O-]</smiles>

(f)<smiles>N[Pb](N)(Cl)Cl</smiles>

(j)<smiles>CCCC1(C(=O)O[P+](N)(N)N)CC1</smiles>

(k) (g)<smiles>N[C@@]12N[C@@H]3CCCC[C@]3(N)N1OC(=O)C2=O</smiles>

(1)<smiles>[O-]S([O-])(O)[S-]</smiles>

(m)

Figure 1: Structures of (a) L-glutathione, (b) L-cysteine, (c) N-acetyl-L-cysteine, (d) the seleno-bis(S-glutathionyl) arsinium ion, (e) oxidized L-glutathione, (f) meso-2,3-dimercaptosuccinic acid, (g) diethylenetriaminepentaacetic acid, (h) 2,3-dimercapto-1-propanesulfonic acid, (i) arsenobetaine, (j) cis-platin, (k) carboplatin, (l) oxaliplatin, and (m) sodium thiosulfate.

("the sum is more than its parts") [66], whose perturbation by a toxin requires appropriate visualization tools [67, 68]. Despite this trend, it needs to be stressed that it does not matter in principle whether one starts "bottom-up" or "topdown" to solve a particular toxicological problem at hand, since the overall goal is to obtain new insight by whatever means [69]. Ultimately, the information that is obtained by either approach should corroborate that of the other to validate a novel toxicological mechanism of action.

Based on the overall focus of this paper to stress the unique niche that LC-based methodologies occupy in "metal species in biology" research, it is divided into four parts. The first one provides an overview of "bottom-up" LC approaches which have provided insight into the reaction of toxic metals with relevant endogenous ligands. Part two summarizes the results of "bottom-up" LC approaches which have contributed to better understand the interaction of metal-based drugs with individual ligands. Part three reviews "top-down" LC approaches which have been applied to study the interaction of toxic metals with blood plasma and their abstraction from proteins by chelating agents. The last part aims to highlight investigations that have employed "topdown" LC approaches to investigate the metabolism of metalbased drugs in blood plasma and/or cells. Owing to this rather broad overall scope, a few select examples which illustrate in what way each LC approach has allowed insight will be presented. To further stress the role that LC played in these studies, the element-specific detector(s) that were employed will only be identified if it was deemed to be useful for the reader.

\section{Interaction of Absorbed/Injected Metal Species with Endogenous Ligands}

In principle, the toxicity of any metal species may be attributed to interactions with endogenous target ligands that occur either in the bloodstream [70] \{in case of a gastrointestinally absorbed metal, one must also consider metal-amino acid complexes, since these may be the species that are absorbed into the bloodstream [71]; with regard to the metal-based drugs cis-platin (Figure 1(j)) or carboplatin (Figure $1(\mathrm{k})$ ), only their hydrolysis product(s) may 
appreciably interact with endogenous ligands [53]\} and/or within organs $[72,73]$. It is also important to note that the biological response of an organism to any given metal species is dose-dependent ("the dose makes the poison") and that a different set of endogenous ligands appear to be targeted in acute [74] as opposed to chronic As ${ }^{\text {III }}$ toxicity [64]. Blood plasma alone may contain up to 10,000 potential protein ligands [75]. Given the large number of possible metal speciesligand interactions and considering that these occur in water [76] - which is considerably more complicated to predict from a thermodynamic point of view than interactions that take place in aprotic solvents [77] - it is unsurprising that they remain rather poorly understood with regard to environmentally abundant toxic metals $[35,78]$ as well as metal-based drugs [79-81].

In the bloodstream the ligand(s) which a particular metal species will bind to is determined by (a) its affinity for each available binding site (e.g., on plasma proteins, external membrane receptors, and/or on cell membranes [85]) and (b) the relative concentration of all binding sites [86]. This binding event often involves the coordination of the metal species to nitrogen, oxygen, and sulfur donor atoms on peptides and proteins [87]. In principle, a metal speciesligand interaction may be either reversible (noncovalent bonding), irreversible (covalent bonding [82]) or involve an actual chemical reaction (e.g., cis-platin reduces $\mathrm{S}-\mathrm{S}$ bonds in human serum albumin, HSA [88]). Reversible interactions between a metal species and endogenous ligands in the bloodstream play a central role in the distribution of the former within the organism, as they will-together with the relative availability of uptake mechanisms into organs [89] - determine the toxicological target $\operatorname{organ}(\mathrm{s})[35,90]$. Irreversible interactions between a metal species and a particular ligand in the bloodstream-which are the result of a chemical reaction [91] - are of particular relevance [32, 84, 91] as they can exert far-reaching systemic adverse health effects at the organ level if the ligand is an essential ultratrace element, such as Se (Figure 2, red arrows). Once the metal species and/or its metabolites enter(s) a particular organ cell, processes (a) and (b) will unfold anew within the cytosol, albeit with a different set of proteins and at reducing conditions, since all mammalian cells contain between $0.1-10 \mathrm{mM}$ glutathione (GSH, Figure 1(a)) [92]. The intracellularly formed metalligand complex may then either disrupt vital biochemical processes in the cytosol $[93,94]$ or enter subcellular compartments (e.g., mitochondria, lysosomes, and nuclei [95]) where (a) and (b) will unfold and may result in cell death [96-98] (Figure 2, dashed red arrows).

Although interactions of metal species with endogenous ligands that occur in the bloodstream are in principle as toxicologically relevant as those that unfold within organs [32], the former may be more important than we currently think. This is because irreversible interactions in this central biological compartment may result in systemic toxicity (Figure 2, red arrows), whereas reversible interactions will be involved in determining the target organ (Figure 2, dashed red arrows). In human blood plasma, the 20 most abundant plasma proteins - they comprise $\sim 97 \%$ of the total protein [99] and

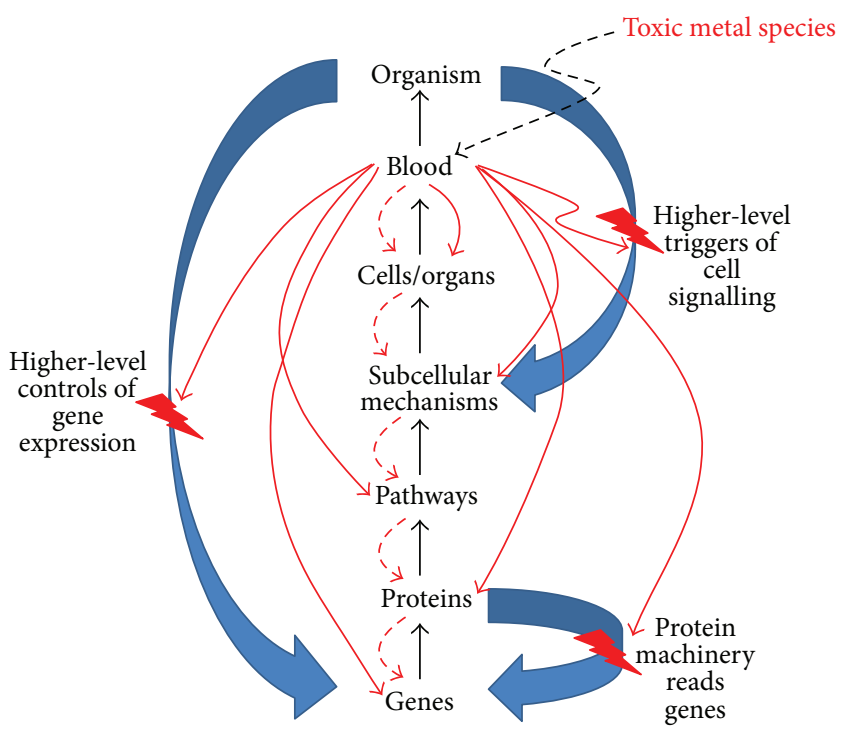

FIgUre 2: Conceptual depiction of the reductionist causal chain to construct an organism (black arrows) as well as the systems biology view of downward causation (blue arrows) adapted from [69]. There are two principle ways by which a toxic metal species that has entered the bloodstream may exert adverse health effects. Red arrows: a metal species interacts with an endogenous target ligand in the bloodstream (e.g., formation of compounds with As-Se and $\mathrm{Hg}$-Se bonds [32, 82]; binding of cis-platin derived hydrolysis products with HSA block the $\mathrm{Zn}^{2+}$ binding site [83] or the displacement of $\mathrm{Zn}$ from the extracellular glycoprotein $\mathrm{Cu}, \mathrm{Zn}$ superoxide dismutase [26]) which may affect cell signalling, gene expression, and/or the distribution of an essential ultratrace element to organs and therefore affect the whole organism [84]. Dashed red arrows: a metal species enters a specific cell type where it interacts with intracellular target ligands (e.g., binding of cis-platin derived hydrolysis products to DNA [55]) to induce apoptosis. Note that the red arrows pertain to all organs within an organism (systemic toxicity), whereas the dashed red arrows correspond to the target organ only (selective toxicity). In the context of developing more targeted metal-based anticancer drugs, it is therefore critical not only to increase their selective toxicity (i.e., their preferential delivery toward cancer cells), but also to minimize/avoid systemic toxicity caused by unintended interactions with endogenous ligands in the bloodstream [83].

almost half of them are $\mathrm{Cu}, \mathrm{Fe}$, and $\mathrm{Zn}$-metalloproteins [100] - have so far received most attention as target ligands for metal species. By far the most abundant plasma protein human serum albumin (HSA), for example, has binding sites for $\mathrm{Cd}^{2+}[101]$, cis-platin derived hydrolysis products [80], and numerous other metal species [102]. Despite the fact that extensive research has been directed to investigate the interaction of individual metal species with individual plasma proteins ("bottom-up" approach), comparatively few studies have attempted to probe the interaction of metal species with more than one ligand (which is the norm in biological systems), with whole plasma/blood in vitro, let alone in vivo ("top-down" approach). A comprehensive understanding of all interactions that unfold in vivo is particularly challenging, since the biotransformation/metabolism of a metal species either in the bloodstream $[32,34,35,53,61,84,91]$ or in 
the liver (from which metabolites may be expelled back into the bloodstream for urinary excretion) may result in species that could also bind to particular plasma proteins over time. Considering the logistical challenges that are generally associated with the execution of in vivo studies, it is not surprising that our understanding of the metabolism of metal species is incomplete. Our lack of understanding the biomolecular basis of the side-effects of intravenously administered metal-based drugs may be similarly attributed to the comparatively few studies that have been conducted to probe their interactions and that of their hydrolysis products with extracellular (plasma proteins) and intracellular (cytosolic) proteins $[103,104]$. Ultimately, the outcome of any metal species that has entered a mammalian organism and interacted with a variety of endogenous ligands will be that it is either deposited as an insoluble and possibly nontoxic complex (e.g., in case of mercury or arsenic [105-107]) or that the parent metal species together with its metabolites is excreted in urine as has been reported for Pt-based anticancer drugs [108] or in feces as is the case for $\mathrm{Hg}^{2+}, \mathrm{CH}_{3} \mathrm{Hg}^{+}, \mathrm{Cd}^{2+}$, $\mathrm{As}^{\mathrm{III}}$ and $\mathrm{Pb}^{2+}[109]$.

\section{Why Use LC to Probe Interactions of Metal Species with Endogenous Ligands?}

A large variety of instrumental techniques have been applied to study interactions between individual metal species and endogenous ligands, including heteronuclear NMR spectroscopy [112], electrospray-ionization mass spectrometry (ESI-MS) [113], extended X-ray absorption fine structure spectroscopy (EXAFS) [113-115], and electron paramagnetic resonance spectroscopy (EPR) [116]. Since none of the aforementioned techniques can probe the platinum speciation at micromolar concentrations inside cells [117], however, there is a need for methods that are capable of monitoring the reaction of $\mathrm{Pt}$ compounds in biological fluids [118]. In this context, one may ask what specific information LC can provide in terms of probing the interaction of a metal species with endogenous ligands? This question will be answered and discussed later (see Sections 4-8). In addition, what practical advantages are there in using an LC approach? One advantage of LC approaches is the fact that the required equipment, such as HPLC pumps as well as the ICP-based detectors (needed to monitor metal species in the column effluent) are available in many analytical laboratories. In addition, near physiological conditions during the LC separation can be maintained by using phosphate-buffered saline (PBS)-buffer (note that certain seemingly useful biological buffers must be strictly avoided to preclude the generation of artifacts when blood plasma is analyzed [119]) and thermostating the LC column. With regard to "top-down" LC approacheswhich generally involve the analysis of a complex biological sample (e.g., blood plasma) with an LC separation system that is coupled online to a ICP-detector-the analytical result will be inherently less complex than that of conventional proteomic techniques [120]. This, in turn, greatly facilitates the interpretation of the obtained results [100]. Another advantage of "top-down" LC approaches is that they allow one to rapidly analyze a biological fluid. The plasma metalloproteome, which is defined as all $\mathrm{Cu}, \mathrm{Fe}$ and $\mathrm{Zn}$ metalloproteins that are present in plasma, for example, can be obtained in $<25 \mathrm{~min}$ [100]. Importantly, this capability opens the door to probe dynamic processes that involve metal species in biological fluids in vitro in almost real time. Given that the analysis of any biological fluid by "top down" LC approaches essentially results in the detection of multiple metal peaks, it is important to point out that the analysis of collected metal-containing fractions with some of the aforementioned techniques (e.g., ESI-MS [119], EXAFS [121], or immunoassays [100]) can provide vital information to structurally characterize a detected novel metal species in order to gain insight into a bioinorganic mechanism of action.

\section{4. "Bottom-Up" LC Approaches to Probe the Interaction of Toxic Metals with Endogenous Ligands}

The interaction of immobilized metal ions for protein ligands is specifically exploited in the LC-based methodology referred to as immobilized metal affinity chromatography (IMAC) [122]. Since IMAC has been successfully applied to gain insight into the binding of $\mathrm{Co}^{2+}, \mathrm{Ni}^{2+}, \mathrm{Cu}^{2+}$, and $\mathrm{Zn}^{2+}$ to serum albumins from different mammalian organisms [123], one may anticipate that IMAC has also been applied to study the interaction of toxic metals with biological ligands. Few studies have been applied to probe the interaction of toxic metals (e.g., $\mathrm{Hg}^{2+}$ ) with endogenous ligands by this approach [124]. LC-based approaches, however, have been applied to investigate the interaction of toxic metals with relevant endogenous ligands although in a different manner (see below). In terms of choosing relevant endogenous ligands, L-glutathione (GSH) must be considered, as this tripeptide is found in a large variety of mammalian cells (including erythrocytes) at intracellular concentrations up to $10 \mathrm{mM}$ [125]. The vital role that GSH plays in critical biochemical detoxification reactions (e.g., the degradation of $\mathrm{H}_{2} \mathrm{O}_{2}$ [126]) and the affinity that it exhibits for several toxic metals based on Pearson's HSAB principle [127] makes it a toxicologically highly relevant target. GSH has, in fact, been referred to as the first line of defense against the acute toxicity of $\mathrm{Cd}^{2+}$ and $\mathrm{Hg}^{2+}$ $[128,129]$, and its reaction with numerous toxic metals has therefore been extensively investigated [130]. The interaction of GSH with toxic metals/metalloid compounds, however, is not only relevant with regard to their acute toxicity, but also their chronic toxicity, since the formation of complexes can result in the activation of the metal/metalloid [131]. Since Lcysteine (Cys, Figure 1(b)) is present in hepatocyte cytosol at $0.2-0.5 \mathrm{mM}$ [126] and at $10 \mu \mathrm{M}$ in blood plasma [132], it represents another toxicologically relevant endogenous ligand. Because of its structural analogy to Cys, N-acetyl-Lcysteine (NAC, Figure 1(c)) is another potentially interesting ligand.

4.1. Interaction of a Toxic Metal with a Single Ligand. The interaction of a single toxic metal with GSH has been studied using size-exclusion chromatography (SEC) employing the "retention analysis method" (Figure 3(a)). The latter was 
Information obtained

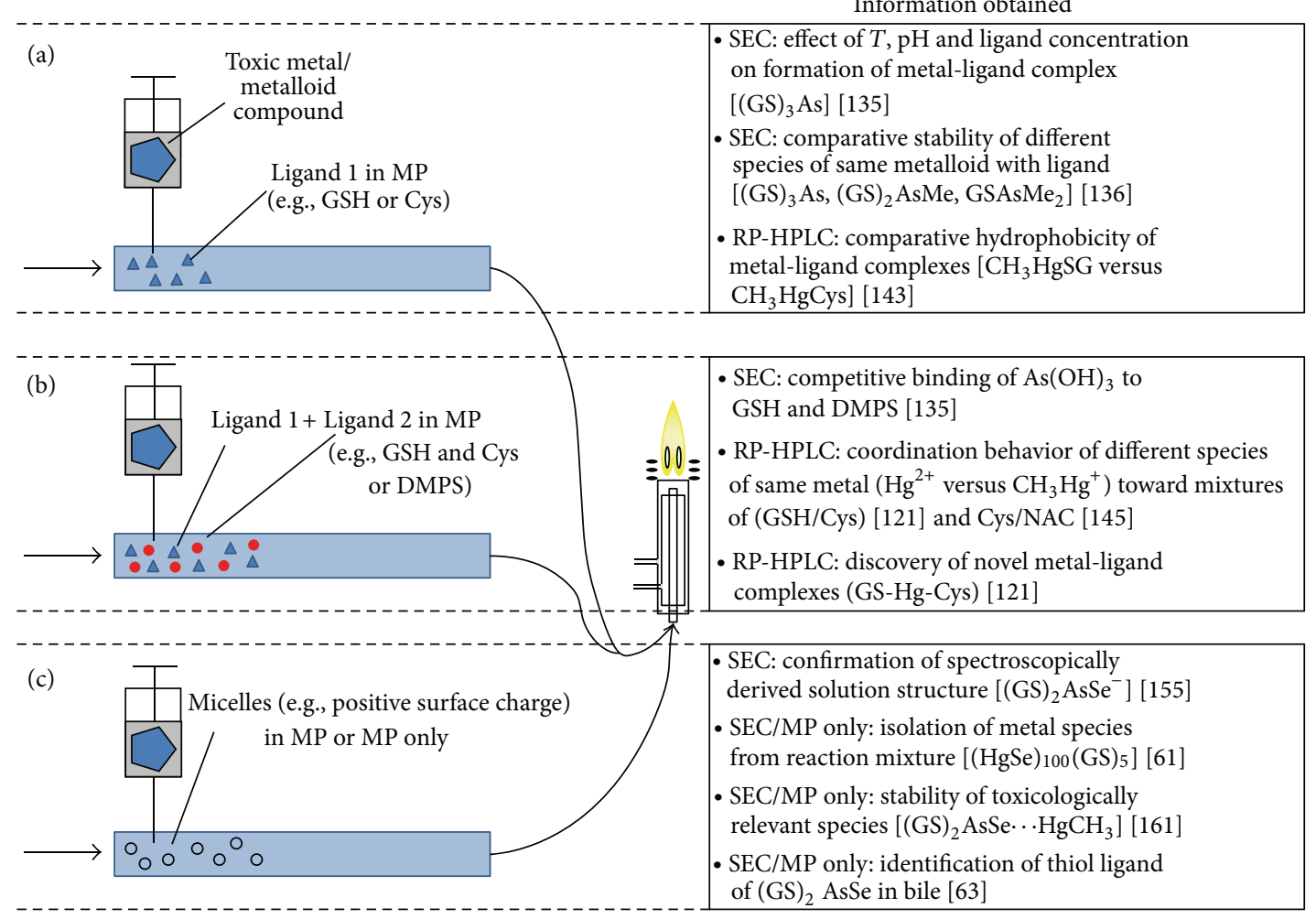

FIGURE 3: “Bottom-up" LC approaches which have been employed to probe interactions between toxic metals and endogenous ligands. (a) The retention time of the toxic metal is measured as a function of the ligand concentration in the mobile phase, the $\mathrm{pH}$, or the column temperature. (b) The retention time of the toxic metal/metalloid compound is measured as a function of an increasing concentration of Ligand 2 while leaving the concentration of Ligand 1 in the mobile phase constant. (c) The retention time of the metal-containing entity is measured as a function of an increased concentration of micelles in the mobile phase. Abbreviations: size exclusion chromatography (SEC), reversed-phase high performance liquid chromatography (RP-HPLC), mobile phase buffer (MP), L-glutathione (GSH), L-cysteine (Cys), and 2,3-dimercapto-1-propanesulfonic acid (DMPS).

originally conceived to study the binding of L-tryptophan to HSA [133, 134], which involved the measurement of the retention volume of the former as a function of the HSA concentration in the mobile phase. A progressive decrease in the retention time of L-tryptophan with an increase in the HSA concentration indicated a binding event, since the on-column formed L-tryptophan-HSA complex was excluded from the pores of the stationary phase. Hence, this LC approach was deemed to be potentially useful to investigate the interaction between a toxic metal with an endogenous ligand at near physiological conditions. Conceptually, the dynamic equilibrium between the metal-species (injected) and the endogenous ligand (in the mobile phase) is kept constant throughout the entire chromatographic process (Figure 3(a)), which is closely related to what happens when a toxic metal enters a ligand-laden biological compartment, such as blood plasma or a cell (Figure 4).

Using the aforementioned approach and employing a Sephadex G-10 SEC column and PBS-buffer ( $\mathrm{pH}$ 7.4) as the mobile phase, the reaction between arsenite $\left[\mathrm{As}(\mathrm{OH})_{3}\right]$ and GSH (1) was investigated [135]:

$$
\begin{aligned}
& \mathrm{As}(\mathrm{OH})_{3}+x \mathrm{GSH} \\
& \quad \longrightarrow(\mathrm{GS})_{x} \mathrm{As}(\mathrm{OH})_{3-x}+x \mathrm{H}_{2} \mathrm{O}, \quad x=1-3 .
\end{aligned}
$$

The injection of $30 \mu \mathrm{g}$ As in form of $\mathrm{As}(\mathrm{OH})_{3}$ onto this system resulted in the elution of an As peak after the inclusion volume which was indicative of an unknown interaction with the stationary phase backbone. The addition of $0.5 \mathrm{mM} \mathrm{GSH}$ to the mobile phase decreased the retention time of the injected $\mathrm{As}(\mathrm{OH})_{3}$ and was rationalized in terms of the formation of (GS) $)_{x}$ As complexes $(x=1-3)$. Applying this LC approach, the effects of $\mathrm{pH}$ (range 210), column temperature $\left(4,25\right.$ and $\left.37^{\circ} \mathrm{C}\right)$, and the $\mathrm{GSH}$ concentration $(0.5-7.5 \mathrm{mM})$ on the formation of $(\mathrm{GS})_{x}$ As complexes were investigated. It was found that their formation was facilitated by low temperatures $\left(4^{\circ} \mathrm{C}\right), \mathrm{pH} 6.0-$ 8.0 , and high GSH concentrations $(7.5 \mathrm{mM})$. Simulating the physicochemical conditions of erythrocyte cytosol ( $3.0 \mathrm{mM} \mathrm{GSH}$ ) and hepatocytes ( $7.5 \mathrm{mM} \mathrm{GSH}$ ) by adding the corresponding GSH concentrations to the mobile phase ( $\mathrm{pH}$ 7.4) and maintaining the column to $37^{\circ} \mathrm{C}$ provided evidence for the formation of $(\mathrm{GS})_{x}$ As complexes. To ascertain that the GSH-induced retention shift of the injected $\mathrm{As}(\mathrm{OH})_{3}$ to shorter retention times was truly caused by the formation of (GS) $)_{x}$ As complexes, the chelating agent 2,3-dimercapto1-propanesulfonate (DMPS, Figure 1(h)) was added (1.0 and $2.0 \mathrm{mM}$ ) to a $7.5 \mathrm{mM}$ GSH containing mobile phase. As expected, the injection of $\mathrm{As}(\mathrm{OH})_{3}$ shifted the elution of 


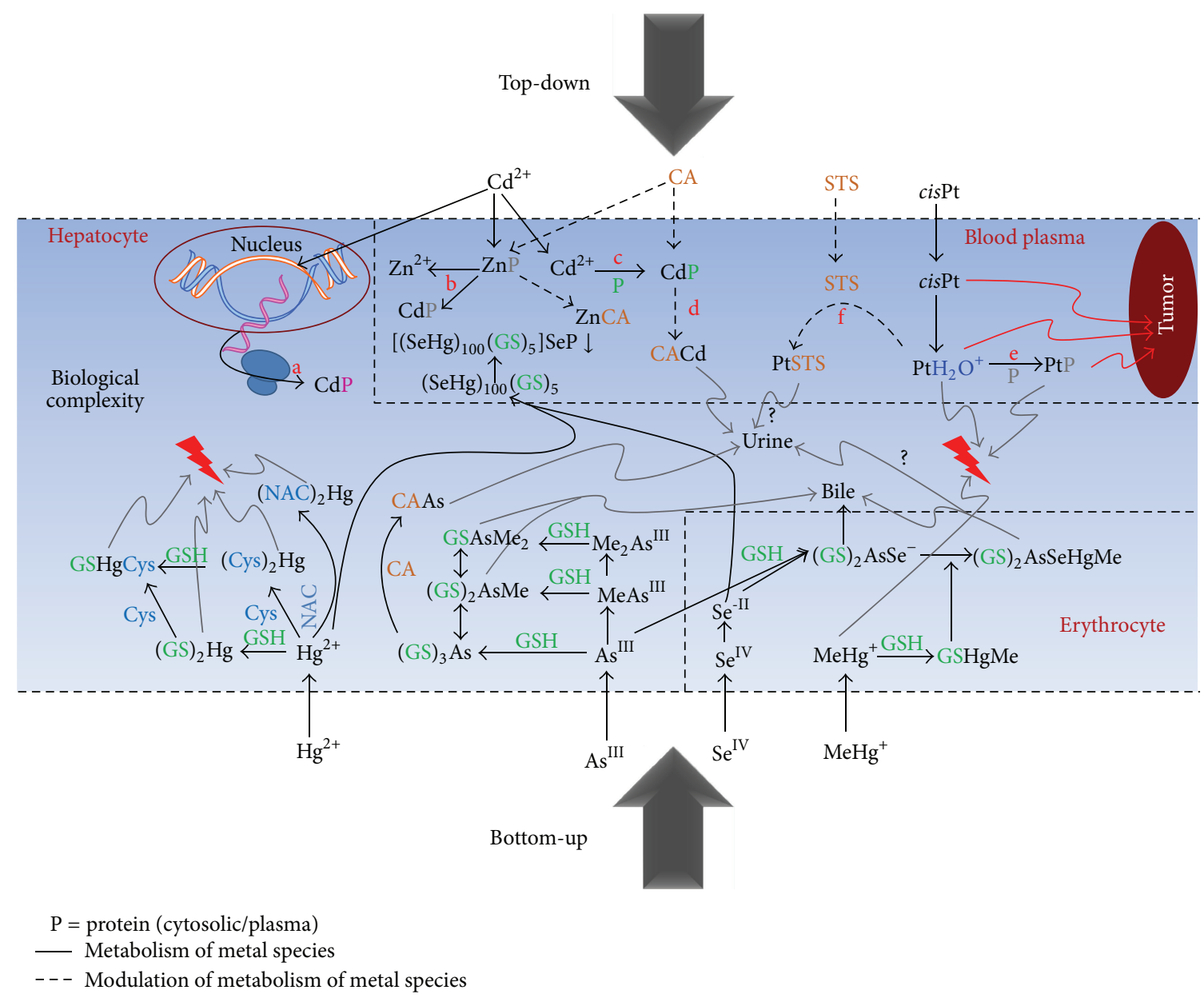

FIGURE 4: Unraveling the metabolism of metal species is a prerequisite to gain deeper insight into the molecular basis of their adverse health effects in mammalian organisms. Toxicologically relevant interactions between metal species and endogenous ligands unfold in blood plasma, erythrocytes and hepatocytes and can be investigated by applying "bottom-up" or "top-down" techniques. Interactions between toxic metals $\left(\mathrm{Hg}^{2+}, \mathrm{As}^{\mathrm{III}}, \mathrm{Se}^{\mathrm{IV}}, \mathrm{CH}_{3} \mathrm{Hg}^{+}\right)$and small molecular weight ligands (GSH, Cys, NAC) that unfold within erythrocytes and/or hepatocyte cytosol and have been studied with "bottom up" LC approaches (Figure 3). Interactions between metal species (Cd ${ }^{2+}$, cis Pt) and cytosolic and plasma proteins have been studied using "top-down" LC-based approaches. (a) Detection of Cd-metallothionein complexes in liver cytosol [110]. (b) Displacement of $\mathrm{Zn}^{2+}$ from a plasma metalloprotein by $\mathrm{Cd}^{2+}$ [26]. (c) Binding of $\mathrm{Cd}^{2+}$ to plasma proteins [26, 36, 111]. (d) Abstraction of Cd ${ }^{2+}$ from plasma proteins by chelating agents (CA) [36]. (e) Comparative binding of cis-platin/carboplatin to plasma proteins [53]. (f) Modulation of the interaction between cis-platin and plasma proteins by sodium thiosulfate (STS) [37]. Note that the combined application of "bottomup" and "top-down" approaches will be required to better understand the interplay between metal species, small molecular weight ligands and proteins to ultimately unravel their adverse health effects and to develop better mitigation strategies by modulating their metabolism by the administration of chelating agents/ameliorating agents.

the As peak toward the inclusion volume which was rationalized in terms of the stronger binding of $\mathrm{As}(\mathrm{OH})_{3}$ to the vicinal dithiol groups of DMPS (chelate effect) as compared to GSH (monothiol, Figure 1(a)). Thus, this principle LC approach allowed insight into the dynamic on-column formation of $(\mathrm{GS})_{x}$ As species under near physiological conditions. To obtain the same information with other techniques, such as ${ }^{1} \mathrm{H}-\mathrm{NMR}$ can be challenging because of line-broadening phenomena at higher temperatures and a comparative lack of sensitivity [135]. In addition, the chosen LC approach can be ideally employed to study competitive interactions between a toxic metal/metalloid compound and two ligands by dissolving them in the mobile phase (i.e., GSH and DMPS). The disadvantages of this approach are that no complex formation constant can be extracted and that the structural characterization of an on-column formed metal-peptidecomplex by ESI-MS is next to impossible due to the utilization of PBS-buffer and the excess GSH therein. In addition, no information about the specific binding site on the employed ligand can be obtained (this information, however, can be easily obtained by ${ }^{1} \mathrm{H}-\mathrm{NMR}$ spectroscopy). Overall, this LC approach nevertheless provided unique insight into the physicochemical conditions under which the highly toxic metalloid species $\mathrm{As}(\mathrm{OH})_{3}$ will react with $\mathrm{GSH}$ to form labile (GS) $)_{x}$ As complexes.

Encouraged by this outcome, this LC approach was also applied to study the interaction of other As ${ }^{\text {III }}$ compounds, 
namely methylarsonous acid $\left[\mathrm{MeAs}(\mathrm{OH})_{2}\right]$ and dimethylarsinous acid $\left[\mathrm{Me}_{2} \mathrm{AsOH}\right]$ with GSH [136]. Both of these methylated $\mathrm{As}{ }^{\mathrm{III}}$ compounds are of toxicological significance because their GS-complexes methylarsonous diglutathione $\left[(\mathrm{GS})_{2} \mathrm{AsMe}\right]$ and dimethylarsinous glutathione [GSAsMe $\left.{ }_{2}\right]$ are believed to play a pivotal role during the methylation of $\mathrm{As}(\mathrm{OH})_{3}$ in the mammalian liver [137-139]. To probe these interactions, a Sephadex G-15 SEC column was used. In order to mimic the physico-chemical conditions that are prevalent in protein-free hepatocyte cytosol [136], the mobile phase was comprised of $10.0 \mathrm{mM}$ GSH in PBSbuffer. Varying the column temperature between 4, 25, and $37^{\circ} \mathrm{C}, 10 \mu \mathrm{g}$ of As in form of $\mathrm{As}(\mathrm{OH})_{3}$, methylarsonous acid $\left[\mathrm{MeAs}(\mathrm{OH})_{2}\right]$, dimethylarsinous acid $\left[\mathrm{Me}_{2} \mathrm{AsOH}\right]$, or arsenobetaine (AsB, Figure 1(i)) were chromatographed separately. AsB eluted in the inclusion volume irrespective of the column temperature, which indicated that it did not form a complex with GSH. At $4^{\circ} \mathrm{C}$, the injection of $\mathrm{As}(\mathrm{OH})_{3}$ resulted in the elution of $(\mathrm{GS})_{3}$ As which was inferred from its elution before a $\sim$ MW 600 GSSG standard. Interestingly, an increase of the column temperature from $4^{\circ} \mathrm{C}$ to $37^{\circ} \mathrm{C}$ progressively shifted the elution of the injected $\mathrm{As}(\mathrm{OH})_{3}$ toward the inclusion volume, whereas the retention times of the injected $\mathrm{MeAs}(\mathrm{OH})_{2}$ and $\mathrm{Me}_{2} \mathrm{AsOH}$ remained essentially unchanged [136]. These findings implied that the As-S bonds in $\mathrm{MeAs}(\mathrm{GS})_{2}$ and $\mathrm{Me}_{2} \mathrm{AsGS}$ are comparatively more stable than those in (GS) ${ }_{3}$ As. This is toxicologically relevant because all of these GS-complexes are substrates for ATP-driven hepatocyte export pumps which are located at the apical and the basolateral side of hepatocytes [138-140]. The efflux of GS-conjugates from hepatocytes to the bloodstream, for example, can be mediated by multidrug resistant protein 1 (MRP1) [140, 141]. It is therefore conceivable that the more stable species $\mathrm{MeAs}(\mathrm{GS})_{2}$ and $\mathrm{Me}_{2} \mathrm{AsGS}$ are more efficiently expelled from hepatocytes to the bloodstream via a MRP than the comparatively unstable (GS) ${ }_{3}$ As (Figure 5 ). If this more efficient efflux of $\mathrm{MeAs}(\mathrm{GS})_{2}$ and $\mathrm{Me}_{2}$ AsGS compared to (GS) ${ }_{3}$ As by a MRP is experimentally confirmed, it would provide a potential explanation for the evolution of hepatic enzymes that methylate $\mathrm{As}(\mathrm{OH})_{3}$. This is because organisms that had developed the capability to methylate $\mathrm{As}(\mathrm{OH})_{3}$ to $\mathrm{MeAs}(\mathrm{OH})_{2}$ and $\mathrm{Me}_{2} \mathrm{AsOH}$ in the liver would more efficiently efflux As ${ }^{\mathrm{III}}$ via the kidneys [136] and therefore have an evolutionary advantage.

More recently, this LC approach was applied to systematically develop a RP-HPLC separation of mercuric mercury $\left(\mathrm{Hg}^{2+}\right)$ and methylmercury $\left(\mathrm{CH}_{3} \mathrm{Hg}^{+}\right)$based on using aqueous mobile phases and GSH or Cys as mobile phase modifiers (Figure 3(a)). Optimal separation was achieved with $10 \mathrm{mM}$ Cys in $50 \mathrm{mM}$ phosphate-buffer (pH 7.5) and using a Gemini RP-HPLC column [143]. During the optimization process, the $\mathrm{pH}$ dependent retention behavior of $\mathrm{Hg}^{2+}$ and $\mathrm{CH}_{3} \mathrm{Hg}^{+}$ was investigated by separately injecting these mercurials using a GSH or Cys-containing mobile phase. Between $\mathrm{pH}$ 5 and 8 , the formation of complexes between $\mathrm{CH}_{3} \mathrm{Hg}^{+}$and each thiol was essentially independent of the mobile phase, whereas the formation of complexes between $\mathrm{Hg}^{2+}$ and GSH was unaffected in the $\mathrm{pH}$ range $6.0-8.0$, but strikingly

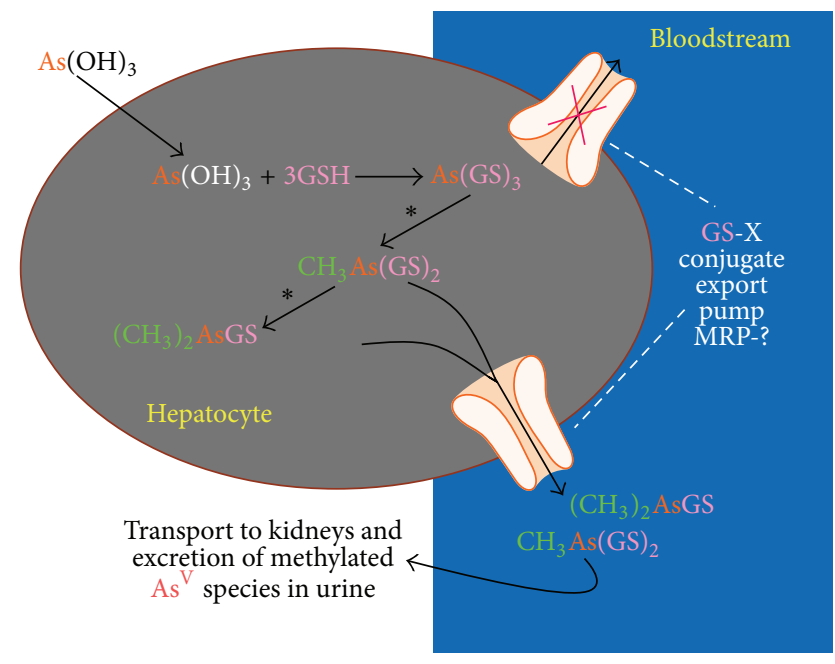

FIGURE 5: Proposed model which can provide a feasible explanation for the evolution of enzymes which methylate $\mathrm{As}^{\mathrm{III}}$ in hepatocytes: $\mathrm{As}(\mathrm{OH})_{3}$ is enzymatically converted $(*)$ to the trivalent As compounds $\mathrm{MeAs}(\mathrm{OH})_{2}$ and $\mathrm{Me}_{2} \mathrm{AsOH}$, which readily react with cytosolic glutathione (GSH) to $\mathrm{MeAs}(\mathrm{GS})_{2}$ and $\mathrm{Me}_{2}$ AsGS. The increased stability of As-S bonds in $\mathrm{MeAs}(\mathrm{GS})_{2}$ and $\mathrm{Me}_{2} \mathrm{AsGS}$ compared to the much less stable (GS) ${ }_{3}$ As will facilitate the efflux of the former species to the bloodstream by MRP export pumps [136]. The translocation of these species to the kidneys and subsequent oxidation will result in the excretion of methylated $\mathrm{As}^{\mathrm{V}}$ species in urine [142].

different at $\mathrm{pH} 5.0$ and 5.5. The stronger retention of the complexes that were formed between each mercurial and GSH (GS-Hg-SG and GS-Hg- $\mathrm{CH}_{3}$ ) compared to the structurally related Cys (Cys-Hg-Cys and Cys- $\mathrm{Hg}-\mathrm{CH}_{3}$ ) was attributed to the comparatively greater hydrophobicity of GSH. The observed differences in the hydrophobicity of these metal complexes may be of toxicological significance, as this physicochemical characteristic is likely to play an important role during the intracellular disposition of $\mathrm{Hg}^{2+}$ and $\mathrm{CH}_{3} \mathrm{Hg}^{+}$ [144].

4.2. Interaction of a Toxic Metal with Two Endogenous Ligands. Most recently, the aforementioned RP-HPLC separation of $\mathrm{Hg}^{2+}$ and $\mathrm{CH}_{3} \mathrm{Hg}^{+}$was improved because the on-column formed $\mathrm{Hg}^{2+}$ complex essentially eluted in the void volume. This improvement was achieved by partially replacing Cys of the mobile phase by the comparatively more hydrophobic NAC (Figures 1(c) and 3(b), respectively). A baseline separation of $\mathrm{Hg}^{2+}$ and $\mathrm{CH}_{3} \mathrm{Hg}^{+}$with the former species being retained was achieved with $7.5 \mathrm{mM} \mathrm{NAC}$ and $2.5 \mathrm{mM}$ Cys in $50 \mathrm{mM}$ phosphate buffer ( $\mathrm{pH}$ 7.4) [145]. The separation was attributed to the formation of comparatively more hydrophobic mercurial-complexes with NAC compared to Cys. The observed formation of hydrophobic $\mathrm{Hg}^{2+}$-NAC complexes (at physiological $\mathrm{pH}$ ) is of potential relevance to explain why the administration of rats with NAC effectively protected them against the nephrotoxicity of $\mathrm{HgCl}_{2}$ [146]. In addition, the formation of a $\mathrm{CH}_{3} \mathrm{Hg}$-NAC complex at $\mathrm{pH} 7.4$ may be involved in the profound NAC-induced mobilization of 


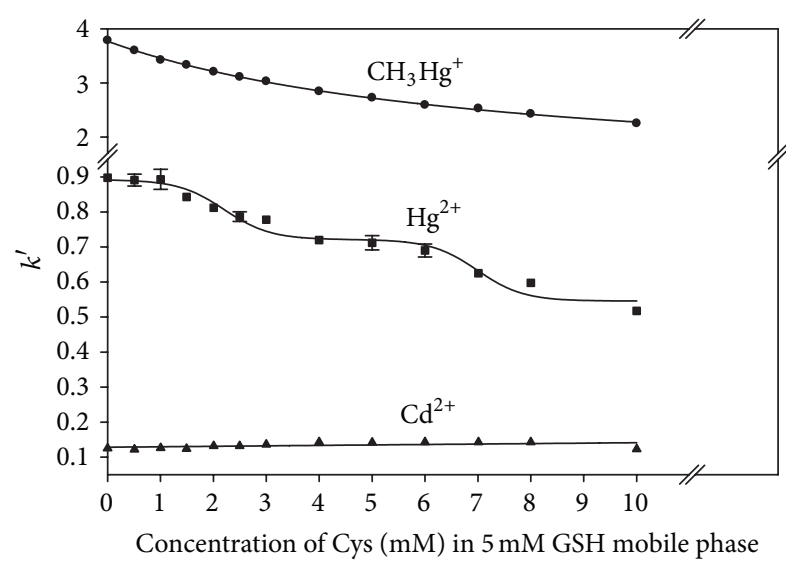

FIgURE 6: Retention behavior of $\mathrm{Hg}^{2+}, \mathrm{CH}_{3} \mathrm{Hg}^{+}$, and $\mathrm{Cd}^{2+}$ on a Gemini C18 RP-HPLC column $(150 \times 4.6 \mathrm{~mm}$ I.D. $)$ at $37^{\circ} \mathrm{C}$. Mobile phase: $5.0 \mathrm{mM}$ GSH with $0-10 \mathrm{mM}$ Cys in PBS buffer (pH 7.4). Flow rate: $1.0 \mathrm{~mL} / \mathrm{min}$. Detector: ICP-AES (Hg at $194.227 \mathrm{~nm}$ or Cd at $226.502 \mathrm{~nm})$. Injection volume: $20 \mu \mathrm{L}(5 \mu \mathrm{g} \mathrm{Hg}$ or Cd). Detached symbols on right side correspond to the $k^{\prime}$ of each metal species using PBS buffer with $5.0 \mathrm{mM}$ Cys as the mobile phase. Errors in $k^{\prime}$ are within the area of plot markers unless otherwise indicated (reproduced with permission from [121] and Elsevier).

$\mathrm{CH}_{3} \mathrm{Hg}^{+}$from tissue compartments (including the brain!) to urine which was observed in mice [147] and possibly involves the renal organic anion transporter-1 (OAT-1) [148]. Considering that the clearance of $\mathrm{Hg}^{2+}$ from organs was not accelerated by NAC in mice [147] and taking into account that NAC did not alter the plasma concentration and the urinary excretion of the essential metals $\mathrm{Ca}, \mathrm{Mg}, \mathrm{Fe}, \mathrm{Zn}$, and $\mathrm{Cu}$ in humans after the administration of an oral dose of $600 \mathrm{mg} /$ day for 2 weeks [149], this thiol ligand appears to be rather selective for the mobilization of $\mathrm{CH}_{3} \mathrm{Hg}^{+}$. Since NAC is inexpensive, well tolerated by patients (it is used to treat acetaminophen toxicity), and was orally effective to remove nearly $90 \%$ of $\mathrm{C} \mathrm{CH}_{3} \mathrm{Hg}^{+}$dose in mice within 2 days, further investigations should explore the utility of NAC as an antidote against $\mathrm{CH}_{3} \mathrm{Hg}^{+}$in clinical settings $[147,150]$.

The aforementioned results indicated that this LC approach is amenable to study the interaction between a toxic metal with two ligands. Although this very idea may at first seem irrelevant considering the underlying biological complexity, one must not forget that the individual concentrations of GSH and Cys in hepatocyte cytosol may greatly exceed those of every single cytosolic protein [121]. Hence, interactions of a toxic metal with these thiols may play an important role in their intracellular distribution [72, 73]. Such competitive interactions can be investigated with LC by leaving the concentration of ligand $\mathrm{A}$ in the mobile phase constant and observing the retention behavior of the metal species of interest as a function of increasing concentrations of ligand B in the mobile phase (Figure 3(b)) [121]. Using a Gemini RP-HPLC column $\left(37^{\circ} \mathrm{C}\right)$ and a mobile phase that was comprised of 5.0 mM GSH in PBS-buffer ( $\mathrm{pH} 7.4$ ), $5 \mu \mathrm{g}$ of $\mathrm{Hg}^{2+}, \mathrm{CH}_{3} \mathrm{Hg}^{+}$, or $\mathrm{Cd}^{2+}$ were separately injected (Figure 6). A single Cd-species eluted essentially in the void volume $\left(k^{\prime}=0.1\right)$, which was structurally characterized as tetrahedral (GS) ${ }_{4} \mathrm{Cd}$ by X-ray absorption spectroscopy (XAS). In contrast, $\mathrm{a} \mathrm{Hg}^{2+}$ species - presumably the linear GS-Hg-SGwas somewhat retained on this column $\left(k^{\prime}=0.9\right)$, whereas a $\mathrm{CH}_{3} \mathrm{Hg}^{+}$species was retained considerably $\left(k^{\prime}=3.8\right)$ (Figure 6). When Cys was incrementally added to the $5.0 \mathrm{mM}$ GSH containing mobile phase $(0.5 \mathrm{mM} / 1.0 \mathrm{mM}$ increments up to $10 \mathrm{mM}$ ) and each metal species was injected, the retention time of $\mathrm{Cd}^{2+}$ remained unchanged. The retention time of the injected $\mathrm{CH}_{3} \mathrm{Hg}^{+}$continuously decreased and was rationalized in terms of the rapid displacement of GSmoieties from $\mathrm{CH}_{3} \mathrm{Hg}^{+}$by more hydrophilic Cys-moieties. In contrast, the retention behavior of $\mathrm{Hg}^{2+}$ displayed a characteristic stepwise decrease of its retention time with gradually increasing Cys concentrations. This behavior was explained in terms of the consecutive displacement of two GS-moieties that were coordinated to $\mathrm{Hg}^{2+}$ by Cys-moieties. These results revealed fundamental differences with regard to the $\mathrm{Hg}-\mathrm{S}$ bonding in these mercury complexes and provided direct experimental evidence for the formation of the proposed species GS-Hg-Cys [151] under near physiological conditions.

4.3. Interaction of Two or Three Toxic Metals with One Endogenous Ligand. To elucidate in what way the interplay of toxic metals with endogenous ligands may contribute to the etiology of disease processes [34], one must be aware of the fact that in reality human populations are rarely exposed to a single toxic metal [152]. Furthermore, toxic metals are always ingested together with essential elements and the metabolism of certain combinations of toxic metals and essential elements may therefore be biochemically intertwined and of toxicological significance. Direct experimental evidence in support of this possibility was reported in 1941, when the simultaneous administration of rats with $\mathrm{As}(\mathrm{OH})_{3}$ and selenite $\left(\mathrm{HSeO}_{3}{ }^{-}\right)$ an essential ultratrace element-resulted in the mutual detoxification of these individually highly toxic metalloid species [153]. Considering that free selenite has been detected in human blood plasma [154], this intriguing trace element antagonism was hypothesized to be implicated in the chronic toxicity of $\mathrm{As}(\mathrm{OH})_{3}$. Investigations aimed at uncovering its biomolecular basis revealed that it appeared to be based on the rapid in vivo assembly of the seleno-bis(S-glutathionyl) arsinium ion, (GS) ${ }_{2} \mathrm{AsSe}^{-}$(Figure $1(\mathrm{~d})$ ) in the bloodstream (in erythrocytes [91]) followed by its translocation to the plasma, the liver and its eventual excretion in bile $[62,64]$. Since the structure of this species was entirely derived from EXAFS and Raman spectroscopy, its unequivocal confirmation required an alternative technique. Surprisingly, this at first difficult task could be accomplished using an LC-based approach. To synthesize $(\mathrm{GS})_{2} \mathrm{AsSe}^{-}$, equimolar $\mathrm{As}(\mathrm{OH})_{3}$ and $\mathrm{HSeO}_{3}{ }^{-}$are reacted at physiological $\mathrm{pH}$ with $\geq 8$ moleequivalents GSH as follows:

$$
\begin{aligned}
\mathrm{As}(\mathrm{OH})_{3} & +\mathrm{HSeO}_{3}{ }^{-}+8 \mathrm{GSH} \\
& \longrightarrow(\mathrm{GS})_{2} \mathrm{AsSe}^{-}+3 \mathrm{GSSG}+6 \mathrm{H}_{2} \mathrm{O}
\end{aligned}
$$

Given that the obtained reaction mixture was supposed to contain (GS) ${ }_{2} \mathrm{AsSe}^{-}$and 3 mole equivalents of GSSG 
(Figure $1(\mathrm{e})$ ), the only notable difference between these species is their net charge: -3 on $(\mathrm{GS})_{2} \mathrm{AsSe}^{-}$and -2 on GSSG (see Figures 1(d) and 1(e)). Thus, a LC-based separation approach that could exploit this charge difference would indirectly confirm the spectroscopically derived structure. It was surmised that the separation of these species might be possible by employing a micellar chromatography approach based on SEC (Figure 3(c)) and the detection of the corresponding species by ICP-AES [155]. A Sephadex G-25 SEC column served as the stationary phase, and $0.1 \mathrm{M}$ Trisbuffer with $50 \mathrm{mM}$ hexadecyltrimethylammonium bromide (HDTAB; critical micellar concentration $0.92 \mathrm{mM}, \mathrm{pH}$ 8.0) served as the mobile phase. The analysis of the reaction mixture revealed the elution of a species that contained As, Se, and S, which was reasonably well separated from GSSG. The integration of the obtained S-peaks confirmed that indeed two S-atoms (derived from two GS-entities) coeluted with an As and Se-containing species. Remarkably, the elution of (GS) ${ }_{2} \mathrm{AsSe}^{-}$followed by GSSG implied additional negative charge on the former species and thus corroborated the spectroscopically derived solution structure [155]. To gain insight into the biochemical mechanism of formation of $(\mathrm{GS})_{2} \mathrm{AsSe}^{-}$, equimolar bis-glutathionylarsenous acid $\left[(\mathrm{GS})_{2} \mathrm{AsOH}\right]$ was reacted with $\mathrm{HSe}^{-}$in aqueous solution. Analysis of the reaction mixture on a Sephadex G-10 SEC column using 0.1 M Tris-buffer ( $\mathrm{pH}$ 8.0) as the mobile phase clearly demonstrated that (GS) ${ }_{2} \mathrm{AsSe}^{-}$had formed (this was confirmed by XAS). Thus, the investigated reaction mechanism can explain how (GS) ${ }_{2} \mathrm{AsSe}^{-}$might be formed in vivo [131].

A related trace element antagonism was discovered in 1967 when the coadministration of rats with $\mathrm{HgCl}_{2}$ and $\mathrm{HSeO}_{3}{ }^{-}$resulted in negligible toxicity, whereas essentially all animals in the $\mathrm{HgCl}_{2}$ group died [156]. Although this antagonism was later demonstrated to involve the formation of a nontoxic $\mathrm{Hg} / \mathrm{Se}$ species in the bloodstream [157], the structural characterization of this species remained elusive. To synthesize a model compound that was intended to uncover the molecular basis of this $\mathrm{HgCl}_{2} / \mathrm{HSeO}_{3}{ }^{-}$antagonism, equimolar $\mathrm{HgCl}_{2} / \mathrm{HSeO}_{3}{ }^{-}$was reacted with 5 mole equivalents of GSH in PBS-buffer [61]. The analysis of the obtained black solution by ${ }^{199} \mathrm{Hg}$-NMR spectroscopy, ${ }^{77} \mathrm{Se}-$ NMR spectroscopy, and a variety of mass spectroscopic techniques (e.g., FAB-MS and ESI-MS), however, did not provide any useful information toward the structural characterization of the contained black solution species. It was eventually decided to directly analyze this mixture on a Sephadex G25 SEC column and detecting $\mathrm{Hg}$, Se, and $\mathrm{S}$ by means of an ICP-AES. The analysis of the black solution revealed a single $\mathrm{Hg}$, Se, and S-containing entity which eluted in the void volume followed by GSSG (this indicated that a redox reaction had occurred). Detailed analysis of the obtained S-specific chromatogram implied that 5 GS-moieties were associated with the detected $\mathrm{Hg}$-Se species and EXAFS analysis of the isolated $\mathrm{Hg} / \mathrm{Se} / \mathrm{S}$-species finally revealed this species as $(\mathrm{Hg}-\mathrm{Se})_{100}(\mathrm{GS})_{5}$, a mercuric selenide core with ligation to 5 GS-moieties via S-Se bonds. The analysis of blood plasma obtained from New Zealand white rabbits
25 min after they had been injected with $\mathrm{HgCl}_{2}$ and $\mathrm{HSeO}_{3}{ }^{-}$ revealed that the Se and $\mathrm{Hg}$ near edge XAS spectra most closely resembled those of the synthetic $(\mathrm{Hg}-\mathrm{Se})_{100}(\mathrm{GS})_{5}$. Thus, conventional SEC (without adding any ligand to the mobile phase buffer) coupled with an ICP-AES played a pivotal role in the elucidation of the structural basis of this mineral antagonism.

Evidence in favor of the existence of an even more fascinating "three-way" antagonism between $\mathrm{As}^{\mathrm{III}}, \mathrm{Se}^{\mathrm{IV}}$, and $\mathrm{CH}_{3} \mathrm{Hg}^{+}$- three individually highly toxic metal/metalloid species-was first reported based on feeding experiments with Japanese quail in 1982 [158]. In particular, the survival rates of quail which were fed $\mathrm{CH}_{3} \mathrm{Hg}^{+}\left(10 \mathrm{mg} \mathrm{Hg} \mathrm{kg}{ }^{-1}\right)$ increased from 5 to $75 \%$ (after 16 weeks) when selenite (6 mg Se kg-1) was included into the $\mathrm{CH}_{3} \mathrm{Hg}^{+}$laced diet. Quite counterintuitively, the survival rate increased to $100 \%$ when $\mathrm{As}^{\mathrm{III}}\left(15 \mathrm{mg} \mathrm{As} \mathrm{kg}^{-1}\right)$ was fed together with $\mathrm{Se}^{\mathrm{IV}}$ and $\mathrm{CH}_{3} \mathrm{Hg}^{+}$. Taking into consideration that (GS) ${ }_{2} \mathrm{AsSe}^{-}$is assembled in erythrocyte lysate [91] and that $\mathrm{CH}_{3} \mathrm{Hg}^{+}$is known to cross the erythrocyte membrane [159] and given the high affinity of $\mathrm{CH}_{3} \mathrm{Hg}^{+}$for selenide [160], it was deemed possible that this antagonism might involve the reaction of (GS) ${ }_{2} \mathrm{AsSe}^{-}$with $\mathrm{CH}_{3} \mathrm{Hg}^{+}$within erythrocytes to yield the complex $\left[(\mathrm{GS})_{2} \mathrm{AsSeHgCH}_{3}\right]$. The addition of $\mathrm{CH}_{3} \mathrm{HgOH}$ to (GS) ${ }_{2} \mathrm{AsSe}^{-}$and the analysis of the obtained aqueous solution by EXAFS revealed that the proposed complex had indeed formed [161]. To elucidate if this reaction might also unfold in erythrocytes, rabbit erythrocyte lysate was supplemented with synthetic (GS) ${ }_{2} \mathrm{AsSe}^{-}$and equimolar $\mathrm{CH}_{3} \mathrm{HgOH}$. XAS analysis revealed that $90 \%\left[(\mathrm{GS})_{2} \mathrm{AsSeHgCH}_{3}\right]$ was present. To investigate the stability of this toxicologically relevant species, [(GS) $)_{2} \mathrm{AsSeHgCH}_{3}$ ] was chromatographed on a Sephadex G-15 SEC column using PBS-buffer as the mobile phase and an ICP-AES as the simultaneous As, $\mathrm{Se}, \mathrm{S}$, and $\mathrm{Hg}$ specific detector (Figure 3(c)). The coelution of As, Se and $\mathrm{S}$ was indicative of $(\mathrm{GS})_{2} \mathrm{AsSe}^{-}$and was followed by a $\mathrm{Hg}-$ species. These findings indicated that $\left[(\mathrm{GS})_{2} \mathrm{AsSeHgCH}_{3}\right]$ had dissociated during the chromatographic process and that the Se-Hg bond was labile when PBS-buffer was used as the mobile phase (this, however, does not necessarily imply that this complex is unstable in vivo). Although the biochemical fate of $\left[(\mathrm{GS})_{2} \mathrm{AsSeHgCH}_{3}\right]$ is currently unknown, these results firmly established the plausibility of its formation under near physiological conditions to explain the remarkable "three-way" antagonism.

\section{5. “Bottom-Up" LC Approaches to Probe the Interaction of Metal-Based Drugs with Endogenous Ligands}

Although metal-based drugs constitute a minority among the plethora of medicinal drugs that are in use today [162], their fraction appears to be slowly increasing $[163,164]$. The serendipitously discovered cis-platin, for example, is still one of the world's best selling anticancer drug [165] which is extraordinarily effective to treat certain types of cancers $[166,167]$. Since only two other Pt-based anticancer drugs, carboplatin (Figure 1(k)) and oxaliplatin (Figure 1(l)), 
have received worldwide approval for their treatment of human cancer patients [168], only these three Pt-based drugs will be discussed. For a historical perspective of cis-platin and its proposed mode of action the reader is referred to a recent review [165]. In general, comparatively few studies have been reported in which LC has been employed to study the interaction of these Pt-based drugs with either individual plasma proteins, small molecular peptides (GSH), and/or amino acids (Cys) $[169,170]$. This must be attributed to the fact that this interaction is complicated by the fact that these Pt-drugs produce multiple Pt-containing hydrolysis products [171] which will then bind to plasma proteins [53], thiol-containing biomolecules [170], and/or the pharmacological target DNA [172, 173]. Thus, the few studies that have employed LC to gain insight into the interaction of Pt-based anticancer drugs with plasma proteins effectively studied primarily the protein binding of the in situ generated hydrolysis products. These studies involved the incubation of individual Pt-based drugs with individual plasma proteins (e.g., HSA) at physiologically relevant conditions $(0.1 \mathrm{M} \mathrm{NaCl}$ in $\mathrm{pH} 7.4$ buffer) followed by the subsequent LC-analysis of the reaction mixture at different time intervals. In this manner, the binding of cis-platin to the key plasma protein HSA was investigated [174]. Subsequent studies revealed that both isomers induced the formation of the albumin dimer, with the transisomer exhibiting a much greater tendency to induce protein dimerization [175]. Furthermore, transplatin cleaved the S-S bonds in HSA more readily than cis-platin $[175,176]$. More recent studies investigated the comparative binding of cis-platin to transferrin (Tf) or HSA. After the incubation of $1 \mu \mathrm{M}$ cis-platin with either apotransferrin (Tf, $3 \mathrm{mg} / \mathrm{mL}$ ) or HSA $(30 \mathrm{mg} / \mathrm{mL})$ in $0.9 \% \mathrm{NaCl}$ and $10 \mathrm{mM}$ Tris-acetic acid ( $\mathrm{pH} 7.4$ ), subsequent analysis by anion exchange HPLC-ICP-MS (Mono Q) revealed complete binding of cis-platin derived species to HSA in $24 \mathrm{~h}$ $(\mathrm{Pt} / \mathrm{HSA}$ ratio $=4: 1)$, but only $50 \%$ in case of apo-Tf after $96 \mathrm{~h}(\mathrm{Pt} / \mathrm{apo}-\mathrm{Tf}=1: 1)$ [177]. The fact that the binding of cis-platin derived hydrolysis products to Tf does not involve the displacement of $\mathrm{Fe}$ [178] is of pharmacological relevance, since only the fully $\mathrm{Fe}^{3+}$-loaded $\mathrm{Tf}$ is capable of binding to the Tf receptor on the surface of cells. These findings strongly suggest that cis-platin derived species may enter cancer cells via receptor-mediated endocytosis of Tf [179]. In addition, the comparative binding of cis-platin and a ruthenium(II)arene complex (RAPTA-T) to HSA and Tf (both holo-Tf and apo-Tf) at different molar ratios has been investigated by SEC-ICP-MS [180]. Importantly, these investigations revealed that cis-platin bound to HSA and Tf to the same extent, whereas RAPTA-T showed a marked preference to bind to Tf. In addition, RAPTA-T showed a markedly higher preference for holo-Tf than apo-Tf. Thus, "bottom up" LC approaches allow to assess the comparative binding of metal-based drugs and/or their hydrolysis products to key plasma proteins under near physiological conditions. The results that are derived from such studies allow to predict whether it is likely that an investigated metal-based drug and or its hydrolysis products may enter cells via established pathways.

\section{6. “Top-Down” LC Approaches to Probe the Interaction of Toxic Metals with Endogenous Ligands}

Blood represents the principal medium for the transport of gastrointestinally absorbed nutrients including essential metals as well as dietary toxic metals to organs. Interactions between toxic metals and constituents of the bloodstream may adversely affect the transport of sufficient amounts of essential elements to their intended destinations within an organism $[26,181]$. To this end, the interactions of $\mathrm{As}(\mathrm{OH})_{3}$ and $\mathrm{Hg}^{2+}$ with the essential ultratrace element Se represent the first examples for this toxicological mechanism of action (Figure 2, red arrows) [32, 84]. Thus, the bloodstream in itself represents a biological compartment where relevant mechanisms of action may unfold. Accordingly, the detection of inorganic pollutant-induced biochemical changes in plasma or erythrocyte lysate represents a feasible approach to possibly gain insight into the etiology of pollutant induced adverse health effects in mammals. In this context it is important to stress that everyone who embarks on the quest to probe these interactions should be aware of the difficulty that is associated with sampling a living organism without changing the composition of any given sample before or during the analysis [26, 182]. In principle, one has to distinguish between perturbations that may be detected within minutes after an appropriate dose of a particular toxin has been added to blood plasma in vitro [26] or administered to animals [183] and perturbations that are only detectable in blood plasma or erythrocyte lysate after a given model organism has been exposed to a particular toxin for weeks or months $[184,185]$. With regard to the nature of these perturbations, one must distinguish between those that are displayed at the mRNAlevel [186], the small molecule level [13, 17], the protein level [12], and those at the metalloprotein level $[26,75]$.

At present, numerous proteomic approaches are available to visualize changes of any given proteome over time, such as increased or decreased concentrations of specific proteins (e.g., in erythrocyte lysate [75]), but many of these techniques are time consuming, expensive, and incapable of detecting changes at the metalloprotein level. Conversely, there are comparatively few LC-based approaches that can be employed to determine the "metalloproteome" of any biological fluid. Fortuitously, however, all of these can accomplish this task in a comparatively rapid manner.

The first notable LC-based approaches that were applied to determine the metalloproteome of biological fluids in a truly "top-down" manner are the pioneering studies of K.T. Suzuki who analyzed rat liver cytosol (SEC-AAS) [110] and blood plasma (SEC-ICP-AES) [111]. After the injection of rats with $\mathrm{Cd}^{2+}(0.4 \mathrm{mg} \mathrm{Cd} / \mathrm{kg}$ body wt), blood plasma was analyzed (after 1, 2, 3, 5, 10, 20, and $30 \mathrm{~min}$ ) using a system that was comprised of an Asahipak GS-520 SEC column, $10 \mathrm{mM}$ Tris- $\mathrm{HCl}$ buffer in $0.9 \% \mathrm{NaCl}(\mathrm{pH} 7.4)$ as the mobile phase and an ICP-AES to monitor the emission lines of $\mathrm{S}$, $\mathrm{Cd}, \mathrm{Zn}, \mathrm{Cu}, \mathrm{Fe}$, and $\mathrm{P}$ [111]. At the 3 min time point, the coelution of a single Cd-peak with $\mathrm{Zn}$ and $\mathrm{S}$ implied the binding of $\mathrm{Cd}^{2+}$ to the most abundant plasma protein rat 
serum albumin (RSA). In addition, these authors detected a comparatively broad $\mathrm{Zn}$-peak (which eluted before $\mathrm{Zn}$ RSA) along with a single $\mathrm{Cu}$-peak (ceruloplasmin), and three unidentified and nonbaseline separated Fe-peaks, as well as two unidentified P-entities (a small one in the high molecular weight and an intense one in the $<60 \mathrm{kDa}$ elution range). Interestingly, the analysis of plasma 20 min after the injection revealed that the Cd-peak that was detected after $3 \mathrm{~min}$ was bearly detectable, which implied rapid translocation of $\mathrm{Cd}^{2+}$ from the bloodstream to organs. Concomitantly, the intensity of the broad $\mathrm{Zn}$-peak had increased in intensity compared to that at the $3 \mathrm{~min}$ time point. Collectively, these results demonstrated that the analysis of blood plasma by SEC-ICP-AES can provide valuable insight not only into the direct interaction of a toxic metal ion with biological ligands in blood plasma (i.e., the rapid binding of $\mathrm{Cd}^{2+}$ to RSA and the subsequent translocation of $\mathrm{Cd}^{2+}$ to organs), but also into changes of the metalloproteome (e.g., the observed changes of the $\mathrm{Zn}$-metalloproteome in response to $\mathrm{Cd}^{2+}$ ). More recently, the application of the same analytical approach (stationary phase: Superdex 200 SEC column; mobile phase: PBS-buffer [100]) was applied to analyze rabbit plasma to which increasing doses of $\mathrm{Cd}^{2+}\left(0.5,2\right.$, and $\left.200 \mu \mathrm{g} \mathrm{Cd}^{2+} / \mathrm{mL}\right)$ had been added in vitro [26]. The results revealed at least two $\mathrm{Cd}^{2+}$ binding proteins after the addition of the low $\mathrm{Cd}^{2+}$ doses. At the high $\mathrm{Cd}^{2+}$ dose, however, an altered $\mathrm{Zn}$ metalloproteome pattern was detected which was attributed to a $\mathrm{Cd}^{2+}$-induced displacement of $\mathrm{Zn}^{2+}$ ions from its binding sites on a $\mathrm{Zn}$-metalloprotein - presumably $\mathrm{Cu}, \mathrm{Zn}$ superoxide dismutase-which has been previously observed [187].

LC-based approaches may not only be applied to detect metalloproteins, but can also be employed to detect toxicologically relevant species in complex biological fluids. To this end, it has been reported that (GS) ${ }_{2} \mathrm{AsSe}^{-}$is excreted in rabbit bile after their injection with $\mathrm{As}(\mathrm{OH})_{3}$ and $\mathrm{HSeO}_{3}{ }^{-}$ [62]. Even though the presence of this species was inferred from the analysis of bile by XAS, this technique can inherently not conclusively identify the sulfur donor in this species. The analysis of bile from similarly treated rabbits by SECICP-AES revealed a single As, Se, and S-containing entity and S-containing bile components. The addition of synthetic $(\mathrm{GS})_{2} \mathrm{AsSe}^{-}$to this bile and reanalysis revealed an increased intensity of the As and the Se peak and therefore unequivocally identified GS-moieties as the ligands in the species that is excreted from the liver [63].

In the context of toxic metals interacting with endogenous ligands within organisms, however, their abstraction from proteins by a chelating agent is also eminently health relevant, since a better understanding of these events will directly contribute to the development of safer chelating agents for their effective tissue mobilization. Since the manipulation of the distribution of metal ions in biological organisms is a very complicated process (i.e., not very amenable to theoretical modeling [188]), one relies on empirical evidence from biological experiments to gain insight. This notion is exemplified by the recent application of SEC to systematically assess the efficiency of three chelating agents to abstract $\mathrm{Cd}^{2+}$ from rabbit plasma proteins in vitro [36]. Using a Superdex
200 SEC column, PBS-buffer as the mobile phase and an ICP-AES, the analysis of rabbit plasma that had been spiked with $2.0 \mu \mathrm{g} \mathrm{Cd}^{2+} / \mathrm{mL}$ revealed two distinct Cd-peaks, which were tentatively identified as $\alpha_{2}$-macroglobulin and rabbit serum albumin. The dose-dependent addition of meso2,3-dimercaptosuccinic acid (DMSA, Figure 1(f)), diethylenetriamine pentaacetic acid (DTPA, Figure $1(\mathrm{~g})$ ), or 2,3dimercapto-1-propanesulfonic acid (DMPS) to the Cd-spiked plasma (0.33-0.99 $\mathrm{mM}$ chelating agent) revealed DTPA to be most effective in abstracting $\mathrm{Cd}^{2+}$ from plasma proteins ( $100 \%$ removal at $0.33 \mathrm{mM})$ to a $\mathrm{Cd}^{2+}$-chelate complex which eluted in the $5 \mathrm{kDa}$ elution range. The simultaneous detection of the emission lines of $\mathrm{Ca}, \mathrm{Cu}, \mathrm{Fe}$, and $\mathrm{Zn}$, however, provided arguably the most valuable insight into unintended consequences of the investigated chelating agents. Whereas none of the chelating agents adversely effected the plasma distribution of $\mathrm{Fe}$ at all investigated doses, all of them mobilized $\mathrm{Zn}^{2+}$ from plasma proteins to $\sim 5 \mathrm{kDa} \mathrm{Zn}$-species (at $0.33 \mathrm{mM}$ DTPA removed $80 \%$, DMPS 63\%, and DMSA $29 \%$ ). Furthermore, DTPA resulted in a dose-dependent elution of a [Ca-DTPA $]^{3-}$ complex, which is undesirable from a clinical point of view, since a decrease in the concentration of free plasma $\mathrm{Ca}^{2+}$ is associated with twitching and titanic convulsions in humans [189]. These unintended chelating agent-induced perturbations of the plasma distribution of $\mathrm{Ca}^{2+}$ and $\mathrm{Zn}^{2+}$ could therefore result in the dyshomeostasis of these essential elements in vivo and-if they were repeatedly administered intravenously to patients-potentially result in pathologies [48]. The obtained results were therefore assessed in terms of finding a chelating agent and dose which offer a compromise between maximizing the abstraction of $\mathrm{Cd}^{2+}$ from plasma proteins and minimizing that of $\mathrm{Zn}^{2+}$ and ideally avoiding the complexation of free $\mathrm{Ca}^{2+}$. This compromise was a dose of $0.33 \mathrm{mM}$ DMSA. Based on these in vitro results the employed LC-approach is destined to play an increasingly important role in the context of developing safer chelating agents for the treatment of patients that suffer from metal intoxications [190-192].

\section{7. “Top-Down” LC Approaches to Probe the Interaction of Metal-Based Drugs with Endogenous Ligands}

In the context of the significant recent decline in the number of therapeutic medicinal drugs that are being approved [54, 193], metal-based drugs offer several conceptual advantages compared to molecularly targeted ones that are constructed from organic fragments $[54,162]$, but their side-effects remain a major problem [166]. Owing to the rising costs that are required to bring a new drug to the market [194], the resulting greater scrutiny to the return on $\mathrm{R} \& \mathrm{D}$ investment [195] translates to an increased need to be able to predict the efficacy and potential side-effects of promising drug candidates before expensive clinical studies are initiated [196]. Therefore, a better understanding of the interaction of promising metal-based drug candidates with endogenous ligands is becoming more important, and in vitro studies can offer valuable insight in this regard. In terms of 
developing better metal-based anticancer drugs, for example, their efficacy can be assessed in cell culture experiments using appropriate cancer cell lines (Figure 2, dashed red arrows), but one needs to be aware that this may not be sufficient to predict in vivo activity [197]. The prediction of their systemic side-effects in model organisms or patients (Figure 2, red arrows), however, remains challenging [83]. Conceptually, the side effects that intravenously administered metal-based anticancer drugs, such as cis-platin exert in patients must be attributed to their limited selectivity toward the tumor tissue compared to healthy tissues (they are therefore also referred to as shotgun cytotoxics [162]) and the complex interactions that unfold between the parent drug and its hydrolysis products with plasma proteins [198], erythrocytes [199], or cytosolic ligands [200]. Since interactions between clinically used metal-based drugs and proteins are not well understood [201], in vitro studies with blood plasma may provide insight into the biomolecular basis of their side effects. To this end, comparatively few studies have been conducted which employed "top-down" LC-approaches to probe such interactions [202]. One of the first studies which utilized SEC-ICP-MS to analyze blood serum which had been spiked with cis-platin over a $24 \mathrm{~h}$ period used a Supelco Progel TSK SEC column and $30 \mathrm{mM}$ Tris-buffer (pH 7.2) [198]. An alternative approach for the analysis of rabbit blood plasma was developed by our group using a Superdex 200 SEC column and PBS-buffer as the mobile phase [100]. The developed method was first applied to study the binding of the surrogate metal-based drug arsenobetaine (Figure 1(i)) to human and rabbit blood plasma to which it had been added in vitro [203]. The results revealed that arsenobetaine-which is present in many marine organisms that are frequently used for human consumption-did not bind to plasma proteins $>300 \mathrm{Da}$ over a $6 \mathrm{~h}$ period, which provided a feasible explanation for the rapid excretion of this compound in urine. The first clinically used metal-based drugs that were investigated employing this "top down" LC approach were the anticancer drugs cis-platin and carboplatin [53]. The addition of pharmacologically relevant doses of each Pt-drug to human plasma in vitro and the subsequent analysis of plasma by SEC-ICP-AES over a $24 \mathrm{~h}$ period revealed a considerably faster hydrolysis of cisplatin than carboplatin. In addition, this study revealed that the hydrolysis products of both Pt-compounds appeared to bind to the same plasma proteins. Even though results that are obtained with blood plasma in vitro are in itself insufficient to predict if the same dynamic changes will occur in vivo [204], the fact that cis-platin and carboplatin are known to exhibit entirely different side effects in patients [53] strongly suggests that their interaction with plasma constituents could be involved in mediating their side effects. Another study applied RP-HPLC using a ODS-3 column to analyze rat blood to which oxaliplatin had been added [70]. The results revealed that $4 \mathrm{~h}$ after incubation $53 \%$ of oxaliplatin was associated with erythrocytes and that $58 \%$ of that was bound to cytosolic proteins (the rest was bound to membrane or in the ultrafiltrate). Interestingly, the analysis of erythrocyte lysate revealed several chemically unreactive Pt-containing species (oxaliplatin metabolites which contained GSH or Cys) and the parent oxaliplatin. The analysis of plasma revealed that the major biotransformation products were the main breakdown product of oxaliplatin, $\mathrm{Pt}(\mathrm{dach}) \mathrm{Cl}_{2}$. In addition, Cys and methionine adducts of $\mathrm{Pt}(\mathrm{dach}) \mathrm{Cl}_{2}$ were detected.

In view of the severe side effects of Pt-based anticancer drugs, the intravenous administration of model organisms with so-called ameliorating agents (either shortly before or after the metal-based drug) has been demonstrated to be effective [37]. Sodium thiosulfate (STS), for example, has been demonstrated to effectively ameliorate the side-effects of cis-platin. In order to gain insight into the biomolecular mechanism by which STS may exert this desirable effect, a pharmacologically relevant dose of STS was added to human plasma in vitro before or after a pharmacologically relevant dose of cis-platin. The subsequent determination of the Ptdistribution in plasma by SEC-ICP-AES revealed that a PtSTS complex was formed. Although the structure of this complex has not been elucidated, its formation in blood plasma provides a feasible explanation for the STS-mediated amelioration of the side-effects of cis-platin in mammalian model organisms. Importantly, these results represent a starting point for the systematic exploration of other ameliorating agents in in vitro studies.

\section{Outlook}

The increased anthropogenic emission of toxic metals into the environment [34] will be inevitably associated with an increased influx of inorganic pollutants into the human bloodstream of various populations, including children. An improved understanding of the biochemistry of toxic metals therein as well as in target organs is therefore urgently needed not only to better understand the biomolecular mechanisms of their chronic toxicity, but also to develop inexpensive, efficient, and safe therapies to mitigate toxic metal-induced adverse health effects in affected populations. To date, the application of "bottom-up" LC approaches has provided valuable insight into the formation of toxic metalligand complexes at near physiological conditions $\left\{(\mathrm{GS})_{3}\right.$ As $[135]\}$, their stability $\left\{(\mathrm{GS})_{3} \mathrm{As}, \mathrm{MeAs}(\mathrm{GS})_{2}\right.$ and $\mathrm{Me}_{2} \mathrm{AsGS}$ $[136]$ and $\left.(\mathrm{GS})_{2} \mathrm{AsSeHgCH}_{3}[161]\right\}$, their hydrophobicity $\{\mathrm{GS}-$ $\mathrm{Hg}-\mathrm{SG}$ versus $\mathrm{Cys}-\mathrm{Hg}-\mathrm{Cys}$ and $\mathrm{GS}-\mathrm{Hg}-\mathrm{CH}_{3}$ versus Cys$\mathrm{Hg}_{-} \mathrm{CH}_{3}$ [143], Cys-Hg-Cys versus NAC-Hg-NAC, Cys-Hg$\mathrm{CH}_{3}$ versus NAC-Hg-CH$\left.{ }_{3}[145]\right\}$, provided evidence for the formation of novel species \{Cys-Hg-SG [121]\}, and played an important role in the structural confirmation of a spectroscopically-derived structure $\left\{(\mathrm{GS})_{2} \mathrm{AsSe}^{-}[155]\right\}$. Perhaps most importantly, LC has been shown to be capable of probing the dynamic and competitive binding of a toxic metal to two ligands $\left\{\mathrm{As}(\mathrm{OH})_{3}\right.$ to GSH/DMPS [135], $\mathrm{Hg}^{2+}$ to $\mathrm{Cys} / \mathrm{GSH}, \mathrm{CH}_{3} \mathrm{Hg}^{+}$to $\left.\mathrm{Cys} / \mathrm{GSH}[121]\right\}$. In contrast, "topdown" LC approaches have allowed to investigate the binding of the toxic metal $\mathrm{Cd}^{2+}$ to proteins in plasma in vitro [36] and to visualize a toxic metal induced perturbation $\left(\mathrm{Cd}^{2+}\right.$ displaced $\mathrm{Zn}^{2+}$ from a plasma metalloprotein [26]), which constitutes a relevant mechanism of toxicity [205]. Furthermore, the analysis of bile by SEC-ICP-AES allowed to identify the thiol ligands of the detected As-Se species as GS which established (GS) ${ }_{2} \mathrm{AsSe}^{-}$as the molecular species that is excreted from the liver [63]. Last but not least "top-down" 
LC approaches can be employed to study the dose-dependent abstraction of $\mathrm{Cd}^{2+}$ from plasma proteins by chelating agents [36]. Thus, the application of "bottom-up" and/or "top-down" LC approaches each offers unique, albeit different insights into the metabolism of toxic metals (Figure 4). The combined application of these techniques in conjunction with other techniques can contribute to better understand the interplay of toxic metals with endogenous ligands in mammals. Considering that the exposure of various populations to toxic metals is of increasing societal concern [206-214], LC approaches can be applied to develop practical solutions to address toxic metal-related problems in the near future.

Another societal issue that is indirectly related to metals is the significant decline in the number of therapeutic medicinal drugs that are being approved. This undesirable trend may be reversed if metal-based drugs can be developed that offer improved efficacy and reduced side effects compared to those that are in use today. To this end "bottom-up" LC approaches can provide insight into the binding of a metal-based drug and/or its hydrolysis products to mixtures of key plasma proteins (e.g., HSA, Tf). Results from such studies are useful to predict the absorption of a metal-based drug into the target organ cells via established uptake mechanisms. On the other hand, the addition of a metal-based drug to blood plasma followed by the LC analysis of the obtained mixture allows to simultaneously observe the hydrolysis of the parent drug and the plasma protein binding of the in situ generated hydrolysis products. This approach has considerable potential to advance our understanding of the biochemical fate of established or synthetic metal-based drug candidates in plasma which will contribute to potentially unravel the molecular basis of their side effects. In addition, "top-down" LC approaches are also ideally suited to gain fundamentally new insight into mechanism of action by which ameliorating agents (e.g., NAC) modulate the metabolism of metal-based drugs (e.g., cis-platin) in plasma. LC can therefore play an important role with regard to the development of novel strategies to decrease the adverse health effects of metal-based drugs while leaving their antitumor effect largely intact [37].

\section{Conclusion}

In terms of defining the bioinorganic mechanisms by which metal species exert toxicity which may eventually result in pathologies at the organ level, we are confronted with considerable knowledge gaps. The biomolecular mechanisms which determine the distribution of particular toxic metals to target organs, for example, are largely unknown even though their binding sites on key plasma proteins have been structurally characterized [181]. Similarly, the biomolecular basis of the severe side-effects that clinically used metal-based drugs exert in patients (e.g., the intravenously administered cis-platin) remains elusive, and the mechanisms by which ameliorating agents modulate the metabolism of cis-platin to mitigate its side effects essentially remain a terra incognita. Collectively, this undesirable situation must be attributed to the lack of a comprehensive understanding of the reversible and irreversible interactions that unfold between metal species (and their metabolites) with endogenous ligands in various biological compartments in vivo. Since it is precisely these interactions which define-in their entirety! - the toxicity that any given metal species (or mixtures thereof) will exert at the organ level (Figure 2), the application of "bottom-up" and "top-down" LC-based approaches has the potential to provide much needed insight into toxicologically relevant aspects of metal-ligand interactions under near physiological conditions. The concerted application of LCbased methodologies in conjunction with other advanced spectroscopic techniques will play an important role in the quest to better understand the disposition, the metabolism, the detoxification, the toxicology, the abstraction of toxic metals/metal-based drugs from proteins, and the modulation of the metabolism of metal-based drugs by ameliorating agents. Importantly, the information that can be obtained from such studies must be integrated into the wider biochemical context to establish progressively more refined models of the metabolism of the metal species of interest. Overall, the application of LC to "metal species in biology" related problems has the potential to establish maximum tolerable doses of a given metal species that may be ingested or injected before a particular biological network/system is perturbed, which would facilitate the interpretation of biomonitoring studies [75]. “Top-down" LC approaches are particularly suited to play a leading role in the context of developing better chelating agents to mobilize toxic metals from organisms, to possibly gain insight into the side effects of metal-based drugs, and to identify "ameliorating agents" which may be coadministered along with metal-based drugs to mitigate their often severe side-effects in patients. The interdisciplinary nature of this research endeavor-at the interface of physiology, biology, inorganic chemistry, biochemistry, analytical chemistry, toxicology and medicineis very much in the spirit of the father of LC. In fact, the inscription on M.S. Tswett's gravestone reads "He invented chromatography, separating molecules but uniting peoples." May this notion continue to serve as a guiding principle as LC-based approaches will continue to serve humanity well into the 21 st century.

\section{References}

[1] M. Tswett, "Physical chemical studies on chlorophyll adsorptions," Berichte der Deutschen botanischen Gesellschaft, vol. 24, pp. 316-326, 1906.

[2] A. J. P. Martin and R. L. M. Synge, "A new form of chromatogram employing two liquid phases," Biochemical Journal, vol. 35, pp. 1358-1368, 1941.

[3] L. S. Ettre and K. I. Sakodynskii, "M.S. Tswett and the discovery of chromatography. I: early work (1899-1903)," Chromatographia, vol. 35, no. 3-4, pp. 223-231, 1993.

[4] A. Zotou, "An overview of recent advances in HPLC instrumentation," Central European Journal of Chemistry, vol. 10, no. 3, pp. 554-569, 2012.

[5] K. K. Unger and A. I. Liapis, "Adsorbents and columns in analytical high-performance liquid chromatography: a perspective with regard to development and understanding," Journal of Separation Science, vol. 35, no. 10-11, pp. 1201-1212, 2012. 
[6] D. Ishii, K. Asai, K. Hibi, T. Jonokuchi, and M. Nagaya, "A study of micro-high-performance liquid chromatography. I. Development of technique for miniaturization of high-performance liquid chromatography," Journal of Chromatography, vol. 144, no. 2, pp. 157-168, 1977.

[7] C. G. Horvath, B. A. Preiss, and S. R. Lipsky, "Fast liquid chromatography: an investigation of operating parameters and the separation of nucleotides on pellicular ion exchangers," Analytical Chemistry, vol. 39, no. 12, pp. 1422-1428, 1967.

[8] P. D. McDonald and D. Patrick, "Fifty years of innovation in analysis and purification," Chemical Heritage, vol. 26, no. 2, pp. 32-37, 2008.

[9] M. E. Swartz, "UPLC: an introduction and review," Journal of Liquid Chromatography \& Related Technologies, vol. 28, no. 7-8, pp. 1253-1263, 2005.

[10] L. Anderson and C. L. Hunter, "Quantitative mass spectrometric multiple reaction monitoring assays for major plasma proteins," Molecular \& Cellular Proteomics, vol. 5, no. 4, pp. 573588, 2006.

[11] D. J. States, G. S. Omenn, T. W. Blackwell et al., "Challenges in deriving high-confidence protein identifications from data gathered by a HUPO plasma proteome collaborative study," Nature Biotechnology, vol. 24, no. 3, pp. 333-338, 2006.

[12] S. P. Gygi, B. Rist, T. J. Griffin et al., "Proteome analysis of lowabundance proteins using multidimensional chromatography and isotope-coded affinity tags," Journal of Proteome Research, vol. 1, no. 1, pp. 47-54, 2002.

[13] D. S. Wishart, "Advances in metabolite identification," Bioanalysis, vol. 3, no. 15, pp. 1769-1782, 2011.

[14] K. A. Francesconi and F. Pannier, "Selenium metabolites in urine: a critical overview of past work and current status," Clinical Chemistry, vol. 50, no. 12, pp. 2240-2253, 2004.

[15] R. F. Service, "Proteomics: ponders prime time," Science, vol. 321, no. 5897, pp. 1758-1761, 2008.

[16] J. K. Nicholson and J. C. Lindon, "Systems biology: metabonomics," Nature, vol. 455, no. 7216, pp. 1054-1056, 2008.

[17] S. C. Booth, M. L. Workentine, A. M. Weljie, and R. J. Turner, "Metabolomics and its application to studying metal toxicity," Metallomics, vol. 3, pp. 1142-1152, 2011.

[18] J. van der Greef, P. Stroobant, and R. van der Heijden, "The role of analytical sciences in medical systems biology," Current Opinion in Chemical Biology, vol. 8, no. 5, pp. 559-565, 2004.

[19] L. Hood, "A systems approach to medicine will transform healthcare," in Physical Biology from Atoms to Medicine, A. H. Zewail, Ed., pp. 337-366, Imperial College Press, London, UK, 2008.

[20] G. Xindu and W. Lili, "Liquid chromatography of recombinant proteins and protein drugs," Journal of Chromatography B, vol. 866, no. 1-2, pp. 133-153, 2008.

[21] R. J. McGorrin, "One hundred years of progress in food analysis," Journal of Agricultural and Food Chemistry, vol. 57, no. 18, pp. 8076-8088, 2009.

[22] L. S. Jackson, "Chemical food safety issues in the United States: past, present, and future," Journal of Agricultural and Food Chemistry, vol. 57, no. 18, pp. 8161-8170, 2009.

[23] S. J. Hill, A. Fisher, and M. Foulkes, "Basic concepts and instrumentation for plasma spectrometry," in Inductively Coupled Plasma Spectrometry and Its Applications, S. J. Hill, Ed., pp. 6197, Blackwell Publishing, Ames, Iowa, USA, 2007.

[24] F. van Heuveln, H. Meijering, and J. Wieling, "Inductively coupled plasma-MS in drug development: bioanalytical aspects and applications," Bioanalysis, vol. 4, no. 15, pp. 1933-1965, 2012.
[25] S. Mounicou, J. Szpunar, and R. Lobinski, "Metallomics: the concept and methodology," Chemical Society Reviews, vol. 38, no. 4, pp. 1119-1138, 2009.

[26] J. L. Gómez-Ariza, E. Z. Jahromi, M. González-Fernández, T. García-Barrera, and J. Gailer, "Liquid chromatographyinductively coupled plasma-based metallomic approaches to probe health-relevant interactions between xenobiotics and mammalian organisms," Metallomics, vol. 3, no. 6, pp. 566-577, 2011.

[27] J. P. Barnett, D. J. Scanlan, and C. A. Blindauer, "Protein fractionation and detection for metalloproteomics: challenges and approaches," Analytical and Bioanalytical Chemistry, vol. 402, no. 10, pp. 3311-3322, 2012.

[28] J. Szpunar, "Advances in analytical methodology for bioinorganic speciation analysis: metallomics, metalloproteomics and heteroatom-tagged proteomics and metabolomics," Analyst, vol. 130, no. 4, pp. 442-465, 2005.

[29] R. Dufault, B. LeBlanc, R. Schnoll et al., "Mercury from chloralkali plants: measured concentrations in food product sugar," Environmental Health, vol. 8, article 2, 2009.

[30] D. Gilbert-Diamond, K. L. Cottingham, J. F. Gruber et al., "Rice consumption contributes to arsenic exposure in US women," Proceedings of the National Academy of Sciences of the United States of America, vol. 108, no. 51, pp. 20656-20660, 2011.

[31] H. H. Harris, I. J. Pickering, and G. N. George, "The chemical form of mercury in fish," Science, vol. 301, no. 5637, p. 1203, 2003.

[32] J. Gailer, "Arsenic-selenium and mercury-selenium bonds in biology," Coordination Chemistry Reviews, vol. 251, no. 1-2, pp. 234-254, 2007.

[33] A. Bhatnagar, "Environmental cardiology: studying mechanistic links between pollution and heart disease," Circulation Research, vol. 99, no. 7, pp. 692-705, 2006.

[34] J. Gailer, "Probing the bioinorganic chemistry of toxic metals in the mammalian bloodstream to advance human health," Journal of Inorganic Biochemistry, vol. 108, pp. 128-132, 2012.

[35] E. Z. Jahromi and J. Gailer, "Probing bioinorganic chemistry processes in the bloodstream to gain new insights into the origin of human diseases," Dalton Transactions, vol. 39, no. 2, pp. 329$336,2010$.

[36] E. Z. Jahromi and J. Gailer, "In vitro assessment of chelating agents with regard to their abstraction efficiency of $\mathrm{Cd}^{2+}$ bound to plasma proteins," Metallomics, vol. 4, no. 9, pp. 995-1003, 2012.

[37] M. Sooriyaarachchi, A. Narendran, and J. Gailer, "The effect of sodium thiosulfate on the metabolism of cis-platin in human plasma in vitro," Metallomics, vol. 4, no. 9, pp. 960-967, 2012.

[38] M. Montes-Bayón, K. DeNicola, and J. A. Caruso, "Liquid chromatography-inductively coupled plasma mass spectrometry," Journal of Chromatography A, vol. 1000, no. 1-2, pp. 457476, 2003.

[39] J. López-Barea and J. L. Gómez-Ariza, "Environmental proteomics and metallomics," Proteomics, vol. 6, supplement 1, pp. S51-S62, 2006.

[40] M. A. O. da Silva, A. Sussulini, and M. A. Z. Arruda, "Metalloproteomics as an interdisciplinary area involving proteins and metals," Expert Review of Proteomics, vol. 7, no. 3, pp. 387-400, 2010.

[41] W. Shi and M. R. Chance, "Metalloproteomics: forward and reverse approaches in metalloprotein structural and functional characterization," Current Opinion in Chemical Biology, vol. 15, no. 1, pp. 144-148, 2011. 
[42] W. Mertz, “The essential trace elements," Science, vol. 213, no. 4514, pp. 1332-1338, 1981.

[43] N. C. Andrews and P. J. Schmidt, "Iron homeostasis," Annual Reviews of Physiology, vol. 69, pp. 69-85, 2007.

[44] W. Maret and Y. Li, "Coordination dynamics of zinc in proteins," Chemical Reviews, vol. 109, no. 10, pp. 4682-4707, 2009.

[45] J. T. Rubino and K. J. Franz, "Coordination chemistry of copper proteins: how nature handles a toxic cargo for essential function," Journal of Inorganic Biochemistry, vol. 107, no. 1, pp. 129-143, 2012.

[46] S. M. Yannone, S. Hartung, A. L. Menon, M. W. W. Adams, and J. A. Tainer, "Metals in biology: defining metalloproteomes," Current Opinion in Biotechnology, vol. 23, no. 1, pp. 89-95, 2012.

[47] S. L. Sensi, P. Paoletti, A. I. Bush, and I. Sekler, "Zinc in the physiology and pathology of the CNS," Nature Reviews Neuroscience, vol. 10, no. 11, pp. 780-791, 2009.

[48] K. J. Waldron, J. C. Rutherford, D. Ford, and N. J. Robinson, "Metalloproteins and metal sensing," Nature, vol. 460, no. 7257, pp. 823-830, 2009.

[49] W. Maret, "Metalloproteomics, metalloproteomes, and the annotation of metalloproteins," Metallomics, vol. 2, no. 2, pp. 117-125, 2010.

[50] J. K. Nicholson and I. D. Wilson, "Understanding 'global' systems biology: metabonomics and the continuum of metabolism," Nature Reviews Drug Discovery, vol. 2, no. 8, pp. 668-676, 2003.

[51] J. L. Peters, T. S. Perlstein, M. J. Perry, E. McNeely, and J. Weuve, "Cadmium exposure in association with history of stroke and heart failure," Environmental Research, vol. 110, no. 2, pp. 199206, 2010 .

[52] O. Andersen, "Chemical and biological considerations in the treatment of metal intoxications by chelating agents," MiniReviews in Medicinal Chemistry, vol. 4, no. 1, pp. 11-21, 2004.

[53] M. Sooriyaarachchi, A. Narendran, and J. Gailer, "Comparative hydrolysis and plasma protein binding of cis-platin and carboplatin in human plasma in vitro," Metallomics, vol. 3, no. 1, pp. 49-55, 2011.

[54] T. W. Hambley, "Developing new metal-based therapeutics: challenges and opportunities," Dalton Transactions, no. 43, pp. 4929-4937, 2007.

[55] J. Reedijk, "Why does cisplatin reach guanine-N7 with competing S-donor ligands available in the cell?" Chemical Reviews, vol. 99, no. 9, pp. 2499-2510, 1999.

[56] B. H. Ali and M. S. Al Moundhri, "Agents ameliorating or augmenting the nephrotoxicity of cisplatin and other platinum compounds: a review of some recent research," Food and Chemical Toxicology, vol. 44, no. 8, pp. 1173-1183, 2006.

[57] K. C. M. Campbell, R. P. Meech, J. J. Klemens et al., "Prevention of noise- and drug-induced hearing loss with d-methionine," Hearing Research, vol. 226, no. 1-2, pp. 92-103, 2007.

[58] G. D. Zeevalk and W. J. Nicklas, "Mechanisms underlying initiation of excitotoxicity associated with metabolic inhibition," Journal of Pharmacology and Experimental Therapeutics, vol. 257, no. 2, pp. 870-878, 1991.

[59] S. Cestèle and W. A. Catterall, "Molecular mechanisms of neurotoxin action on voltage-gated sodium channels," Biochimie, vol. 82, no. 9-10, pp. 883-892, 2000.

[60] K. Cottingham, "Systems biology: a boon for analytical chemists?" Analytical Chemistry, vol. 77, no. 9, pp. 197A-200A, 2005.

[61] J. Gailer, G. N. George, I. J. Pickering et al., "Structural basis of the antagonism between inorganic mercury and selenium in mammals," Chemical Research in Toxicology, vol. 13, no. 11, pp. 1135-1142, 2000.

[62] J. Gailer, G. N. George, I. J. Pickering et al., "A metabolic link between arsenite and selenite: the seleno-bis( $S$ - glutathionyl) arsinium ion," Journal of the American Chemical Society, vol. 122, no. 19, pp. 4637-4639, 2000.

[63] J. Gailer, S. Madden, G. A. Buttigieg, M. B. Denton, and H. S. Younis, "Identification of $\left[(\mathrm{GS})_{2} \text { AsSe }\right]^{-}$in rabbit bile by sizeexclusion chromatography and simultaneous multielementspecific detection by inductively coupled plasma atomic emission spectroscopy," Applied Organometallic Chemistry, vol. 16, no. 2, pp. 72-75, 2002.

[64] J. Gailer, L. Ruprecht, P. Reitmeir, B. Benker, and P. Schramel, "Mobilization of exogenous and endogenous selenium to bile after the intravenous administration of environmentally relevant doses of arsenite to rabbits," Applied Organometallic Chemistry, vol. 18, no. 12, pp. 670-675, 2004.

[65] J. Gailer, G. N. George, I. J. Pickering, R. C. Prince, H. S. Younis, and J. J. Winzerling, "Biliary excretion of $\left[(\mathrm{GS})_{2} \mathrm{AsSe}\right]^{-}$ after intravenous injection of rabbits with arsenite and selenate," Chemical Research in Toxicology, vol. 15, no. 11, pp. 1466-1471, 2002.

[66] P. Hunter, P. Robbins, and D. Noble, "The IUPS human physiome project," Pflügers Archiv, vol. 445, no. 1, pp. 1-9, 2002.

[67] L. Hood, J. R. Heath, M. E. Phelps, and B. Lin, "Systems biology and new technologies enable predictive and preventative medicine," Science, vol. 306, no. 5696, pp. 640-643, 2004.

[68] L. M. Gierasch and A. Gershenson, "Post-reductionist protein science, or putting Humpty Dumpty back together again," Nature Chemical Biology, vol. 5, pp. 774-777, 2009.

[69] D. Noble, The Music of Life, Biology Beyond Genes, Oxford University Press, New York, NY, USA, 2006.

[70] F. R. Luo, S. D. Wyrick, and S. G. Chaney, "Biotransformations of oxaliplatin in rat blood in vitro," Journal of Biochemical and Molecular Toxicology, vol. 13, no. 3-4, pp. 159-169, 1999.

[71] C. Jumarie, C. Fortin, M. Houde, P. G. C. Campbell, and F. Denizeau, "Cadmium uptake by Caco-2 cells: effects of $\mathrm{Cd}$ complexation by chloride, glutathione, and phytochelatins," Toxicology and Applied Pharmacology, vol. 170, no. 1, pp. 29-38, 2001.

[72] R. K. Zalups, "Molecular interactions with mercury in the kidney," Pharmacological Reviews, vol. 52, no. 1, pp. 113-143, 2000.

[73] R. K. Zalups and S. Ahmad, "Molecular handling of cadmium in transporting epithelia," Toxicology and Applied Pharmacology, vol. 186, no. 3, pp. 163-188, 2003.

[74] J. L. Webb, "Arsenicals," in Enzyme and Metabolic Inhibitors, J. L. Webb, Ed., vol. 3, pp. 595-793, Academic Press, London, UK, 1966.

[75] S. A. Manley and J. Gailer, "Analysis of the plasma metalloproteome by SEC-ICP-AES: bridging proteomics and metabolomics," Expert Review of Proteomics, vol. 6, no. 3, pp. 251-265, 2009.

[76] G. Chillemi, G. Mancini, N. Sanna et al., "Evidence for sevenfold coordination in the first solvation shell of $\mathrm{Hg}(\mathrm{II})$ aqua ion," Journal of the American Chemical Society, vol. 129, no. 17, pp. 5430-5436, 2007.

[77] G. M. Whitesides, P. W. Snyder, D. T. Moustakas, and K. A. Mirica, "Designing ligands to bind tightly to proteins," in Physical Biology, from Atoms to Medicine, A. H. Zewail, Ed., pp. 189-215, Imperial College Press, London, UK, 2008. 
[78] J. P. K. Rooney, “The role of thiols, dithiols, nutritional factors and interacting ligands in the toxicology of mercury," Toxicology, vol. 234, no. 3, pp. 145-156, 2007.

[79] A. Casini and J. Reedijk, "Interactions of anticancer Pt compounds with proteins: an overlooked topic in medicinal inorganic chemistry?" Chemical Science, vol. 3, no. 11, pp. 3135-3144, 2012.

[80] A. R. Timerbaev, C. G. Hartinger, S. S. Aleksenko, and B. K. Keppler, "Interactions of antitumor metallodrugs with serum proteins: advances in characterization using modern analytical methodology," Chemical Reviews, vol. 106, no. 6, pp. 2224-2248, 2006.

[81] M. Knipp, "Metallothioneins and platinum(II) anti-tumor compounds," Current Medicinal Chemistry, vol. 16, pp. 522-537, 2009.

[82] J. Gailer, "Reactive selenium metabolites as targets of toxic metals/metalloids in mammals: a molecular toxicological perspective," Applied Organometallic Chemistry, vol. 16, no. 12, pp. 701-707, 2002.

[83] W. Hu, Q. Luo, K. Wu et al., "The anticancer drug cisplatin can cross-link the interdomain zinc site on human albumin," Chemical Communications, vol. 47, no. 21, pp. 6006-6008, 2011.

[84] J. Gailer, "Chronic toxicity of As" in mammals: the role of (GS) ${ }_{2}$ AsSe $^{-}$," Biochimie, vol. 91, no. 10, pp. 1268-1272, 2009.

[85] M. T. Le, J. Gailer, and E. J. Prenner, " $\mathrm{Hg}^{2+}$ and $\mathrm{Cd}^{2+}$ interact differently with biomimetic erythrocyte membranes," BioMetals, vol. 22, no. 2, pp. 261-274, 2009.

[86] N. Ballatori, "Transport of toxic metals by molecular mimicry," Environmental Health Perspectives, vol. 110, no. 5, pp. 689-694, 2002.

[87] R. H. Holm, P. Kennepohl, and E. I. Solomon, "Structural and functional aspects of metal sites in biology," Chemical Reviews, vol. 96, no. 7, pp. 2239-2314, 1996.

[88] B. P. Esposito and R. Najjar, "Interactions of antitumoral platinum-group metallodrugs with albumin," Coordination Chemistry Reviews, vol. 232, no. 1-2, pp. 137-149, 2002.

[89] N. Ballatori and A. T. Truong, "Mechanisms of hepatic methylmercury uptake," Journal of Toxicology and Environmental Health, vol. 46, no. 3, pp. 343-353, 1995.

[90] N. Shimojo, Y. Kumagai, and J. Nagafune, "Difference between kidney and liver in decreased manganese superoxide dismutase activity caused by exposure of mice to mercuric chloride," Archives of Toxicology, vol. 76, no. 7, pp. 383-387, 2002.

[91] S. A. Manley, G. N. George, I. J. Pickering et al., "The seleno bis(S-glutathionyl) arsinium ion is assembled in erythrocyte lysate," Chemical Research in Toxicology, vol. 19, no. 4, pp. 601607, 2006.

[92] A. Meister, "Glutathione metabolism and its selective modification," Journal of Biological Chemistry, vol. 263, no. 33, pp. 17205$17208,1988$.

[93] J. M. Mates, J. A. Segura, and F. J. Alonso, "Roles of dioxins and heavy metals in cancer and neurological diseases using ROSmediated mechanisms," Free Radical Biology and Medicine, vol. 49, no. 9, pp. 1328-1341, 2010.

[94] T. J. Hagele, J. N. Mazerik, A. Gregory et al., "Mercury activates vascular endothelial cell phospholipase D through thiols and oxidative stress," International Journal of Toxicology, vol. 26, no. 1, pp. 57-69, 2007.

[95] S. Bhattacharya, S. Bose, B. Mukhopadhyay et al., "Specific binding of inorganic mercury to Na- K-ATPase in rat liver plasma membrane and signal transduction," BioMetals, vol. 10, no. 3, pp. 157-162, 1997.
[96] D. R. Green and G. Kroemer, "The pathophysiology of mitochondrial cell death," Science, vol. 305, no. 5684, pp. 626-629, 2004.

[97] S. Orrenius and B. Zhivotovsky, "The future of toxicology—does it matter how cells die?" Chemical Research in Toxicology, vol. 19, pp. 729-733, 2006.

[98] J. D. Robertson and S. Orrenius, "Molecular mechanisms of apoptosis Induced by cytotoxic chemicals," Critical Reviews in Toxicology, vol. 30, no. 5, pp. 609-627, 2000.

[99] U. Landegren, J. Vänelid, M. Hammond et al., "Opportunities for sensitive plasma proteome analysis," Analytical Chemistry, vol. 84, no. 4, pp. 1824-1830, 2012.

[100] S. A. Manley, S. Byrns, A. W. Lyon, P. Brown, and J. Gailer, "Simultaneous $\mathrm{Cu}-$, $\mathrm{Fe}-$, and $\mathrm{Zn}$-specific detection of metalloproteins contained in rabbit plasma by size-exclusion chromatography-inductively coupled plasma atomic emission spectroscopy," JBIC Journal of Biological Inorganic Chemistry, vol. 14, no. 1, pp. 61-74, 2009.

[101] P. J. Sadler and J. H. Viles, " $\mathrm{H}$ and ${ }^{113} \mathrm{Cd}$ NMR investigations of $\mathrm{Cd}^{2+}$ and $\mathrm{Zn}^{2+}$ binding sites on serum albumin: competition with $\mathrm{Ca}^{2+}, \mathrm{Ni}^{2+}, \mathrm{Cu}^{2+}$, and $\mathrm{Zn}^{2+}$, Inorganic Chemistry, vol. 35, no. 15, pp. 4490-4496, 1996.

[102] D. C. Carter and J. X. Ho, "Structure of serum albumin," Advances in Protein Chemistry, vol. 45, pp. 153-203, 1994.

[103] V. Sahni, D. Choudhury, and Z. Ahmed, "Chemotherapyassociated renal dysfunction," Nature Reviews Nephrology, vol. 5, pp. 450-462, 2009.

[104] D. Wang and S. J. Lippard, "Cellular processing of platinum anticancer drugs," Nature Reviews Drug Discovery, vol. 4, pp. 307-320, 2005.

[105] F. Caurant, M. Navarro, and J. C. Amiard, "Mercury in pilot whales: possible limits to the detoxification process," Science of the Total Environment, vol. 186, no. 1-2, pp. 95-104, 1996.

[106] M. Korbas, J. L. O. ’Donoghue, G. E. Watson et al., “The chemical nature of mercury in human brain following poisoning or environmental exposure," ACS Chemical Neuroscience, vol. 1, no. 12, pp. 810-818, 2010.

[107] J. P. Berry and P. Galle, "Selenium-arsenic interaction in renal cells: role of lysosomes. Electron microprobe study," Journal of Submicroscopic Cytology and Pathology, vol. 26, no. 2, pp. 203210, 1994.

[108] S. Hann, G. Koellensperger, Z. Stefánka et al., "Application of HPLC-ICP-MS to speciation of cisplatin and its degradation products in water containing different chloride concentrations and in human urine," Journal of Analytical Atomic Spectrometry, vol. 18, pp. 1391-1395, 2003.

[109] Z. Gregus and C. D. Klaassen, "Disposition of metals in rats: a comparative study of fecal, urinary, and biliary excretion and tissue distribution of eighteen metals," Toxicology and Applied Pharmacology, vol. 85, no. 1, pp. 24-38, 1986.

[110] K. T. Suzuki, "Direct connection of high-speed liquid chromatograph (equipped with gel permeation column) to atomic absorption spectrophotometer for metalloprotein analysis: metallothionein," Analytical Biochemistry, vol. 102, no. 1, pp. 3134, 1980.

[111] K. T. Suzuki, H. Sunaga, E. Kobayashi, and N. Shimojo, "Mercaptalbumin as a selective cadmium-binding protein in rat serum," Toxicology and Applied Pharmacology, vol. 86, no. 3, pp. 466-473, 1986.

[112] S. J. Berners-Price and P. J. Sadler, "Coordination chemistry of metallodrugs: insights into biological speciation from NMR 
spectroscopy," Coordination Chemistry Reviews, vol. 151, pp. 140, 1996.

[113] M. Groessl and P. J. Dyson, "Bioanalytical and biophysical techniques for the elucidation of the mode of action of metalbased drugs," Current Topics in Medicinal Chemistry, vol. 11, no. 21, pp. 2632-2646, 2011.

[114] V. Mah and F. Jalilehvand, "Cadmium(II) complex formation with glutathione," JBIC Journal of Biological Inorganic Chemistry, vol. 15, no. 3, pp. 441-458, 2010.

[115] R. Ortega, A. Carmona, I. Llorens, and P. L. Solari, "X-ray absorption spectroscopy of biological samples. A tutorial," Journal of Analytical Atomic Spectrometry, vol. 27, pp. 2054-2065, 2012.

[116] N. Cetinbas, M. I. Webb, J. A. Dubland, and C. J. Walsby, "Serum-protein interactions with anticancer $\mathrm{Ru}(\mathrm{III})$ complexes KP1019 and KP418 characterized by EPR," JBIC Journal of Biological Inorganic Chemistry, vol. 15, no. 2, pp. 131-145, 2010.

[117] Y. Kasherman, S. Sturup, and D. Gibson, "Is glutathione the major cellular target of cisplatin? A study of the interactions of cisplatin with cancer cell extracts," Journal of Medicinal Chemistry, vol. 52, no. 14, pp. 4319-4328, 2009.

[118] D. Gibson, "The mechanism of action of platinum anticancer agents-what do we really know about it?" Dalton Transactions, no. 48, pp. 10681-10689, 2009.

[119] E. Z. Jahromi, W. White, Q. Wu, R. Yamdagni, and J. Gailer, "Remarkable effect of mobile phase buffer on the SEC-ICP-AES derived $\mathrm{Cu}, \mathrm{Fe}$ and $\mathrm{Zn}$-metalloproteome pattern of rabbit blood plasma," Metallomics, vol. 2, no. 7, pp. 460-468, 2010.

[120] C. C. Wu, P. H. Peng, Y. T. Chang et al., "Identification of potential serum markers for nasopharyngeal carcinoma from a xenografted mouse model using Cy-dye labeling combined with three-dimensional fractionation," Proteomics, vol. 8, no. 17, pp. 3605-3620, 2008.

[121] K. L. Pei, M. Sooriyaarachchi, D. A. Sherrell, G. N. George, and J. Gailer, "Probing the coordination behavior of $\mathrm{Hg}^{2+}, \mathrm{CH}_{3} \mathrm{Hg}^{+}$, and $\mathrm{Cd}^{2+}$ towards mixtures of two biological thiols by HPLCICP-AES," Journal of Inorganic Biochemistry, vol. 105, no. 3, pp. 375-381, 2011.

[122] E. K. M. Ueda, P. W. Gout, and L. Morganti, "Current and prospective applications of metal ion-protein binding," Journal of Chromatography A, vol. 988, no. 1, pp. 1-23, 2003.

[123] L. Andersson, E. Sulkowski, and J. Porath, "Immobilized metal ion affinity chromatography of serum albumins.," Bioseparation, vol. 2, no. 1, pp. 15-22, 1991.

[124] L. Gelunaite, V. Lukša, O. Sudžiuviene, V. Bumelis, and H. Pesliakas, "Chelated mercury as a ligand in immobilized metal ion affinity chromatography of proteins," Journal of Chromatography $A$, vol. 904, no. 2, pp. 131-143, 2000.

[125] A. Meister and M. E. Anderson, "Glutathione," Annual Review of Biochemistry, vol. 52, pp. 711-760, 1983.

[126] N. Kaplowitz, T. Y. Aw, and M. Ookhtens, "The regulation of hepatic glutathione," Annual Review of Pharmacology and Toxicology, vol. 25, pp. 715-744, 1985.

[127] K. L. Haas and K. F. Franz, "Application of metal coordination chemistry to explore and manipulate cell biology," Chemical Reviews, vol. 109, no. 10, pp. 4921-4960.

[128] R. K. Singhal, M. E. Anderson, and A. Meister, "Glutathione, a first line of defense against cadmium toxicity," FASEB Journal, vol. 1, no. 3, pp. 220-223, 1987.

[129] A. Naganuma, M. E. Anderson, and A. Meister, "Cellular glutathione as a determinant of sensitivity to mercuric chloride toxicity: prevention of toxicity by giving glutathione monoester," Biochemical Pharmacology, vol. 40, no. 4, pp. 693697, 1990.

[130] D. L. Rabenstein, "Metal complexes of glutathione and their biological significance," in Glutathione: Chemical, Biochemical, and Medical Aspects, D. Dolphin, O. Avramovic, and R. Poulson, Eds., pp. 147-186, John Wiley \& Sons, New York, NY, USA, 1989.

[131] J. Gailer, G. N. George, I. J. Pickering, G. A. Buttigieg, M. B. Denton, and R. S. Glass, "Synthesis, X-ray absorption spectroscopy and purification of the seleno-bis (S-glutathionyl) arsinium anion from selenide, arsenite and glutathione," Journal of Organometallic Chemistry, vol. 650, no. 1-2, pp. 108-113, 2002.

[132] L. H. Lash and D. P. Jones, "Distribution of oxidized and reduced forms of glutathione and cysteine in rat plasma," Archives of Biochemistry and Biophysics, vol. 240, no. 2, pp. 583$592,1985$.

[133] B. Sebille, N. Thuaud, and J. P. Tillement, "Retention data methods for the determination of drug-protein binding parameters by high-performance liquid chromatography," Journal of Chromatography, vol. 204, pp. 285-291, 1981.

[134] B. Sebille and N. Thuaud, "Determination of tryptophanhuman serum albumin binding from retention data and separation of tryptophan enantiomer by high performance liquid chromatography," Journal of Liquid Chromatography, vol. 3, no. 2, pp. 299-308, 1980.

[135] J. Gailer and W. Lindner, "On-column formation of arsenicglutathione species detected by size-exclusion chromatography in conjunction with arsenic-specific detectors," Journal of Chromatography B, vol. 716, pp. 83-93, 1998.

[136] A. J. Percy and J. Gailer, "Methylated trivalent arsenicglutathione complexes are more stable than their arsenite analog," Bioinorganic Chemistry and Applications, vol. 2008, Article ID 539082, 8 pages, 2008.

[137] K. Rehman and H. Naranmandura, "Arsenic metabolism and thioarsenicals," Metallomics, vol. 4, no. 9, pp. 881-892, 2012.

[138] S. V. Kala, M. W. Neely, G. Kala et al., "The MRP2/cMOAT transporter and arsenic-glutathione complex formation are required for biliary excretion of arsenic," Journal of Biological Chemistry, vol. 275, no. 43, pp. 33404-33408, 2000.

[139] E. M. Leslie, "Arsenic-glutathione conjugate transport by the human multidrug resistance proteins (MRPs/ABCCs)," Journal of Inorganic Biochemistry, vol. 108, pp. 141-149, 2012.

[140] E. M. Leslie, R. G. Deely, and S. P. C. Cole, “Toxicological relevance of the multidrug resistance protein $1, \mathrm{MRP} 1(\mathrm{ABCC})$ and related transporters," Toxicology, vol. 167, no. 1, pp. 3-23, 2001.

[141] N. Ballatori, S. M. Krance, R. Marchan, and C. L. Hammond, "Plasma membrane glutathione transporters and their roles in cell physiology and pathophysiology," Molecular Aspects of Medicine, vol. 30, no. 1-2, pp. 13-28, 2009.

[142] R. S. Braman and C. C. Foreback, "Methylated forms of arsenic in the environment," Science, vol. 182, no. 4118, pp. 1247-1249, 1973.

[143] A. J. Percy, M. Korbas, G. N. George, and J. Gailer, "Reversedphase high-performance liquid chromatographic separation of inorganic mercury and methylmercury driven by their different coordination chemistry towards thiols," Journal of Chromatography A, vol. 1156, no. 1-2, pp. 331-339, 2007.

[144] Š. Baláž, M. Wiese, and J. K. Seydel, "A time hierarchy-based model for kinetics of drug disposition and its use in quantitative structure-activity relationships," Journal of Pharmaceutical Sciences, vol. 81, no. 9, pp. 849-857, 1992. 
[145] J. D. Meers, E. Z. Jahromi, B. Heyne, and J. Gailer, "Improved RP-HPLC separation of $\mathrm{Hg}^{2+}$ and $\mathrm{CH}_{3} \mathrm{Hg}^{+}$using a mixture of thiol-based mobile phase additives," Journal of Environmental Science and Health A, vol. 47, no. 1, pp. 149-154, 2012.

[146] G. Girardi and M. M. Elias, "Effectiveness of $N$-acetylcysteine in protecting against mercuric chloride-induced nephrotoxicity," Toxicology, vol. 67, no. 2, pp. 155-164, 1991.

[147] N. Ballatori, M. W. Lieberman, and W. Wang, " $N$-acetylcysteine as an antidote in methylmercury poisoning," Environmental Health Perspectives, vol. 106, no. 5, pp. 267-271, 1998.

[148] A. S. Koh, T. A. Simmons-Willis, J. B. Pritchard, S. M. Grassl, and N. Ballatori, "Identification of a mechanism by which the methylmercury antidotes $N$-acetylcysteine and dimercaptopropanesulfonate enhance urinary metal excretion: transport by the renal organic anion transporter-1," Molecular Pharmacology, vol. 62, no. 4, pp. 921-926, 2002.

[149] E. Hjortsø, J. S. Fomsgaard, and N. Fogh-Andersen, "Does Nacetylcysteine increase the excretion of trace metals (calcium, magnesium, iron, zinc and copper) when given orally?" European Journal of Clinical Pharmacology, vol. 39, no. 1, pp. 29-31, 1990.

[150] L. Chapman and H. M. Chan, "The influence of nutrition on methyl mercury intoxication," Environmental Health Perspectives, vol. 108, no. 1, pp. 29-56, 2000.

[151] R. K. Zalups and L. H. Lash, "Interactions between glutathione and mercury in the kidney, liver, and blood," in Toxicology of Metals, L. W. Chang, Ed., pp. 145-163, CRC Lewis Publishers, Boca Raton, Fla, USA, 1996.

[152] E. Mitchell, S. Frisbie, and B. Sarkar, "Exposure to multiple metals from groundwater-a global crisis: geology, climate change, health effects, testing, and mitigation," Metallomics, vol. 3, no. 9, pp. 874-908, 2011.

[153] K. P. DuBois, A. L. Moxon, and O. E. Olson, "Further studies on the effective ness of arsenic in preventing selenium poisoning," Journal of Nutrition, vol. 19, pp. 477-482, 1940.

[154] B. Michalke, "Selenspeziation mit SAX-ICP-MS und RPLCICP-MS," in Moderne Techniken Der Ionenanalyse, K. Fischer and D. Jensen, Eds., pp. 50-60, ECOMED Verlagsgesellschaft, Landsberg, Germany, 2002.

[155] J. Gailer, S. Madden, M. F. Burke, M. B. Denton, and H. V. Aposhian, "Simultaneous multielement-specific detection of a novel glutathione-arsenic-selenium ion $\left[(\mathrm{GS})_{2} \mathrm{AsSe}\right]^{-}$by ICP AES after micellar size- exclusion chromatography," Applied Organometallic Chemistry, vol. 14, no. 7, pp. 355-363, 2000.

[156] J. Parizek and I. Ostadalova, "The protective effect of small amounts of selenite in sublimate intoxication," Experientia, vol. 23, no. 2, pp. 142-143, 1967.

[157] S. Yoneda and K. T. Suzuki, "Equimolar Hg-Se complex binds to selenoprotein P," Biochemical and Biophysical Research Communications, vol. 231, no. 1, pp. 7-11, 1997.

[158] M. M. El-Begearmi, H. E. Ganther, and M. L. Sunde, "Dietary interaction between methylmercury, selenium, arsenic, and sulfur amino acids in Japanese quail," Poultry Science, vol. 61, no. 2, pp. 272-279, 1982.

[159] A. Naganuma and N. Imura, "Methylmercury binds to a low molecular weight substance in rabbit and human erythrocytes," Toxicology and Applied Pharmacology, vol. 47, no. 3, pp. 613-616, 1979.
[160] Y. Sugiura, Y. Tamai, and H. Tanaka, "Selenium protection against mercury toxicity: high binding affinity of methylmercury by selenium-containing ligands in comparison with sulfurcontaining ligands," Bioinorganic Chemistry, vol. 9, no. 2, pp. $167-180,1978$.

[161] M. Korbas, A. J. Percy, J. Gailer, and G. N. George, "A possible molecular link between the toxicological effects of arsenic, selenium and methylmercury: methylmercury(II) seleno bis(Sglutathionyl) arsenic(III)," JBIC Journal of Biological Inorganic Chemistry, vol. 13, no. 3, pp. 461-470, 2008.

[162] T. W. Hambley, "Chemistry: metal-based therapeutics," Science, vol. 318, no. 5855, pp. 1392-1393, 2007.

[163] K. H. Thompson and C. Orvig, "Boon and bane of metal ions in medicine," Science, vol. 300, no. 5621, pp. 936-939, 2003.

[164] M. J. Abrams and B. A. Murrer, "Metal compounds in therapy and diagnosis," Science, vol. 261, no. 5122, pp. 725-730, 1993.

[165] A. M. Pizarro and P. J. Sadler, "Unusual DNA binding modes for metal anticancer complexes," Biochimie, vol. 91, no. 10, pp. 1198-1211, 2009.

[166] S. Van Zutphen and J. Reedijk, “Targeting platinum anti-tumour drugs: overview of strategies employed to reduce systemic toxicity," Coordination Chemistry Reviews, vol. 249, no. 24, pp. 2845-2853, 2005.

[167] T. W. Hambley, "The influence of structure on the activity and toxicity of Pt anti-cancer drugs," Coordination Chemistry Reviews, vol. 166, pp. 181-223, 1997.

[168] B. W. Harper, A. M. Krause-Heuer, M. P. Grant, M. Manohar, K. B. Garbutcheon-Singh, and J. R. Aldrich-Wright, "Advances in platinum chemotherapeutics," Chemistry, vol. 16, no. 24, pp. 7064-7077, 2010.

[169] J. C. Dabrowiak, J. Goodisman, and A. K. Souid, "Kinetic study of the reaction of cisplatin with thiols," Drug Metabolism and Disposition, vol. 30, no. 12, pp. 1378-1384, 2002.

[170] T. Ishikawa and F. Ali-Osman, "Glutathione-associated cis-diamminedichloroplatinum(II) metabolism and ATP-dependent efflux from leukemia cells. Molecular characterization of glutathione-platinum complex and its biological significance," Journal of Biological Chemistry, vol. 268, no. 27, pp. 20116-20125, 1993.

[171] K. W. Lee and D. S. J. Martin, "Cis-dichlorodiammineplatinum(II). Aquation equilibria and isotopic exchange of chloride ligands with free chloride and tetrachloroplatinate(II)," Inorganica Chimica Acta, vol. 17, pp. 105-110, 1976.

[172] A. V. Klein and T. W. Hambley, "Platinum drug distribution in cancer cells and tumors," Chemical Reviews, vol. 109, no. 10, pp. 4911-4920, 2009.

[173] X. Wang and Z. Guo, "The role of sulfur in platinum anticancer chemotherapy," Anti-Cancer Agents in Medicinal Chemistry, vol. 7, no. 1, pp. 19-34, 2007.

[174] A. I. I. Ivanov, J. Christodoulou, J. A. Parkinson et al., "Cisplatin binding sites on human albumin," The Journal of Biological Chemistry, vol. 273, no. 24, pp. 14721-14730, 1998.

[175] L. Trynda-Lemiesz, H. Kozlowski, and B. K. Keppler, "Effect of cis-, trans-diamminedichloroplatinum(II) and DBP on human serum albumin," Journal of Inorganic Biochemistry, vol. 77, no. 3-4, pp. 141-146, 1999.

[176] N. Ohta, D. Chen, S. Ito, T. Futo, T. Yotsuyanagi, and K. Ikeda, "Effect of trans-diamminedichloroplatinum(II) on human serum albumin: conformational changes through partial disulfide bond cleavage," International Journal of Pharmaceutics, vol. 118, no. 1, pp. 85-93, 1995. 
[177] D. Esteban-Fernández, M. Montes-Bayón, E. B. González, M. M. Gómez-Gómez, M. A. Palacios, and A. Sanz-Medel, "Atomic (HPLC-ICP-MS) and molecular mass spectrometry (ESI-QTOF) to study cis-platin interactions with serum proteins," Journal of Analytical Atomic Spectrometry, vol. 23, pp. 378-384, 2008.

[178] H. Sun, H. Li, and P. J. Sadler, "Transferrin as a metal ion mediator," Chemical Reviews, vol. 99, no. 9, pp. 2817-2842, 1999.

[179] J. M. El Hage Chahine, M. Hemadi, and N. T. Ha-Duong, "Uptake and release of metal ions by transferrin and interaction with receptor," Biochimica et Biophysica Acta, vol.1820, no. 3, pp. 334-347, 2012.

[180] M. Groessl, M. Terenghi, A. Casini, L. Elviri, R. Lobinski, and P. J. Dyson, "Reactivity of anticancer metallodrugs with serum proteins: new insights from size exclusion chromatographyICP-MS and ESI-MS," Journal of Analytical Atomic Spectrometry, vol. 25, no. 3, pp. 305-313, 2010.

[181] A. J. Stewart, C. A. Blindauer, S. Berezenko, D. Sleep, and P. J. Sadler, "Interdomain zinc site on human albumin," Proceedings of the National Academy of Sciences of the United States of America, vol. 100, no. 7, pp. 3701-3706, 2003.

[182] C. B. Kissinger and P. T. Kissinger, "Your bioanalytical data are only as good as your samples," Bioanalysis, vol. 4, no. 12, pp. 1411$1415,2012$.

[183] S. Döker, S. Mounicou, M. Doğan, and R. Lobinski, "Probing the metal-homeostatis effects of the administration of chromium(vi) to mice by ICP MS and size-exclusion chromatographyICP MS," Metallomics, vol. 2, no. 8, pp. 549-555, 2010.

[184] M. Gonzalez-Fernández, M. A. García-Sevilliano, R. JaraBiedma et al., "Size characterization of metal species in liver and brain from free-living (Mus spretus) and laboratory (Mus Musculus) mice by SEC-ICP-MS: application to environmental contamination assessment," Journal of Analytical Atomic Spectrometry, vol. 26, no. 1, pp. 141-149, 2011.

[185] R. Montes-Nieto, C. A. Fuentes-Almagro, D. Bonilla-Valverde et al., "Proteomics in free-living Mus spretus to monitor terrestrial ecosystems," Proteomics, vol. 7, no. 23, pp. 4376-4387, 2007.

[186] J. Riuz-Laguna, N. Abril, T. García-Barrera, J. L. Gómez-Ariza, J. López-Barea, and C. Pueyo, "Absolute transcript expression signatures of Cyp and Gst genes in Mus spretus to detect environmental contamination," Environmental Science \& Technology, vol. 40, no. 11, pp. 3646-3652, 2006.

[187] Y. H. Huang, C. M. Shih, C. J. Huang et al., "Effects of cadmium on structure and enzymatic activity of $\mathrm{Cu}, \mathrm{Zn}-\mathrm{SOD}$ and oxidative status in neural cells," Journal of Cellular Biochemistry, vol. 98, no. 3, pp. 577-589, 2006.

[188] L. E. Scott and C. Orvig, "Medicinal inorganic chemistry approaches to passivation and removal of aberrant metal ions in disease," Chemical Reviews, vol. 109, no. 10, pp. 4885-4910, 2009.

[189] W. B. Cannon, "Organization for physiological homeostasis," Physiological Reviews, vol. 9, no. 3, pp. 399-431, 1929.

[190] W. J. Crinnion and J. Q. Tran, "Organic foods contain higher levels of certain nutrients, lower levels of pesticides, and may provide health benefits for the consumer," Alternative Medicine Review, vol. 15, pp. 303-310, 2010.

[191] L. Charlet, Y. Chapron, P. Faller, R. Kirsch, A. T. Stone, and P. C. Baveye, "Neurodegenerative diseases and exposure to the environmental metals $\mathrm{Mn}, \mathrm{Pb}$, and $\mathrm{Hg}$," Coordination Chemistry Reviews, vol. 256, no. 19-20, pp. 2147-2163, 2012.

[192] G. N. George, R. C. Prince, J. Gailer et al., "Mercury binding to the chelation therapy agents DMSA and DMPS and the rational design of custom chelators for mercury," Chemical Research in Toxicology, vol. 17, no. 8, pp. 999-1006, 2004.

[193] J. W. Scannell, A. Blanckley, H. Boldon, and B. Warrington, "Diagnosing the decline in pharmaceutical R\&D efficiency," Nature Reviews Drug Discovery, vol. 11, pp. 191-200, 2012.

[194] D. Malakoff, “Can treatment costs be tamed?" Science, vol. 331, no. 6024, pp. 1545-1547, 2011.

[195] S. Castellino, "MALDI imaging MS analysis of drug distribution in tissue: the right time!(?)," Bioanalysis, vol. 4, no. 21, pp. 25492551, 2012.

[196] S. Tuncel, F. Dumoulin, J. Gailer et al., "A set of highly watersoluble tetraethyleneglycol-substituted $\mathrm{Zn}$ (II) phthalocyanines: synthesis, photochemical and photophysical properties, interaction with plasma proteins and in vitro phototoxicity," Dalton Transactions, vol. 40, no. 16, pp. 4067-4079, 2011.

[197] J. Moretto, B. Chauffert, F. Ghiringhelli, J. R. Aldrich-Wright, and F. Bouyer, "Discrepancy between in vitro and in vivo antitumor effect of a new platinum(II) metallointercalator," Investigational New Drugs, vol. 29, no. 6, pp. 1164-1176, 2011.

[198] J. Szpunar, A. Makarov, T. Pieper, B. K. Keppler, and R. Lobinski, "Investigation of metallodrug-protein interactions by sizeexclusion chromatography coupled with inductively coupled plasma mass spectrometry (ICP-MS)," Analytica Chimica Acta, vol. 387, no. 2, pp. 135-144, 1999.

[199] R. Mandal, R. Kalke, and X. F. Li, "Interaction of oxaliplatin, cisplatin, and carboplatin with hemoglobin and the resulting release of a heme group," Chemical Research in Toxicology, vol. 17, no. 10, pp. 1391-1397, 2004.

[200] R. Baliga, Z. Zhang, M. Baliga, N. Ueda, and S. V. Shah, "In vitro and in vivo evidence suggesting a role for iron in cisplatininduced nephrotoxicity," Kidney International, vol. 53, no. 2, pp. 394-401, 1998.

[201] V. Calderone, A. Casini, S. Mangani, L. Messori, and P. L. Orioli, "Structural investigation of cisplatin-protein interactions: selective platination of His19 in a cuprozinc superoxide dismutase," Angewandte Chemie, vol. 45, no. 8, pp. 1267-1269, 2006.

[202] X. Sun, C. N. Tsang, and H. Sun, "Identification and characterization of metallodrug binding proteins by (metallo) proteomics," Metallomics, vol. 1, no. 1, pp. 25-31, 2009.

[203] K. L. Pei and J. Gailer, "Probing the interaction of arsenobetaine with blood plasma constituents in vitro: an SEC-ICP-AES study," Metallomics, vol. 1, no. 5, pp. 403-408, 2009.

[204] D. A. Smith, L. Di, and E. H. Kerns, "The effect of plasma protein binding on in vivo efficacy: misconceptions in drug discovery," Nature Reviews Drug Discovery, vol. 9, pp. 929-939, 2010.

[205] M. Kirberger and J. J. Yang, "Structural differences between $\mathrm{Pb}^{2+}$ - and $\mathrm{Ca}^{2+}$-binding sites in proteins: implications with respect to toxicity," Journal of Inorganic Biochemistry, vol. 102, no. 10, pp. 1901-1909, 2008.

[206] J. M. Swanson, S. Entringer, C. Buss, and P. D. Wadhwa, "Developmental origins of health and disease: environmental exposures," Seminars in Reproductive Medicine, vol. 27, no. 5, pp. 391402, 2009.

[207] L. Trasande, P. J. Landrigan, and C. Schechter, "Public health and economic consequences of methyl mercury toxicity to the developing brain," Environmental Health Perspectives, vol. 113, no. 5, pp. 590-596, 2005.

[208] L. D. Hylander and M. E. Goodsite, "Environmental costs of mercury pollution," Science of the Total Environment, vol. 368, no. 1, pp. 352-370, 2006. 
[209] J. J. Wirth and R. S. Mijal, "Adverse effects of low level heavy metal exposure on male reproductive function," Systems Biology in Reproductive Medicine, vol. 56, no. 2, pp. 147-167, 2010.

[210] L. Jarup, "Hazards of heavy metal contamination," British Medical Bulletin, vol. 68, no. 1, pp. 167-182, 2003.

[211] B. H. Robinson, "E-waste: an assessment of global production and environmental impacts," Science of the Total Environment, vol. 408, no. 2, pp. 183-191, 2009.

[212] G. Zheng, X. Xu, K. Wu, T. A. Yekeen, and X. Huo, "Association between lung function in school children and exposure to three transition metals from an e-waste recycling area," Journal of Exposure Science and Environmental Epidemiology, vol. 23, pp. 67-72, 2013.

[213] S.-R. Lim, D. Kang, O. A. Ogunseitan, and J. M. Schoenung, "Potential environmental impacts from the metals in incandescent, compact fluorescent lamp (CFL), and light-emitting diode (LED) bulbs," Environmental Science and Technology, vol. 47, no. 2, pp. 1040-1047, 2013.

[214] Y. Liu, C. Wen, and X. Liu, "China's food security soiled by contamination,” Science, vol. 339, pp. 1382-1383, 2013. 

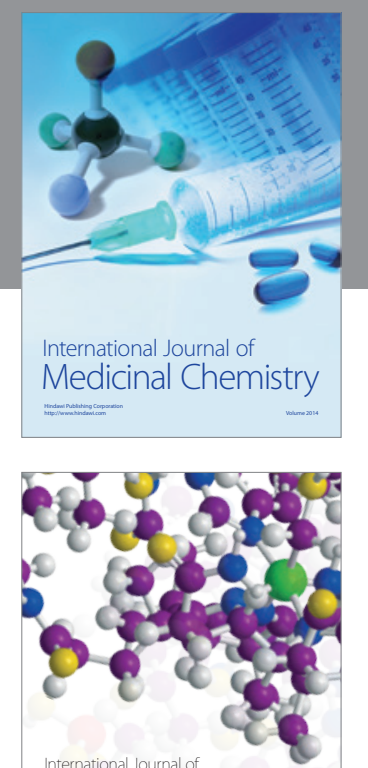

\section{Carbohydrate} Chemistry

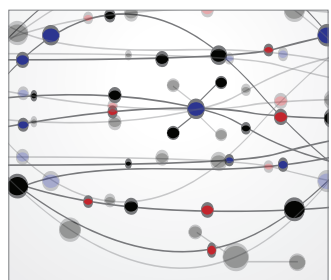

The Scientific World Journal
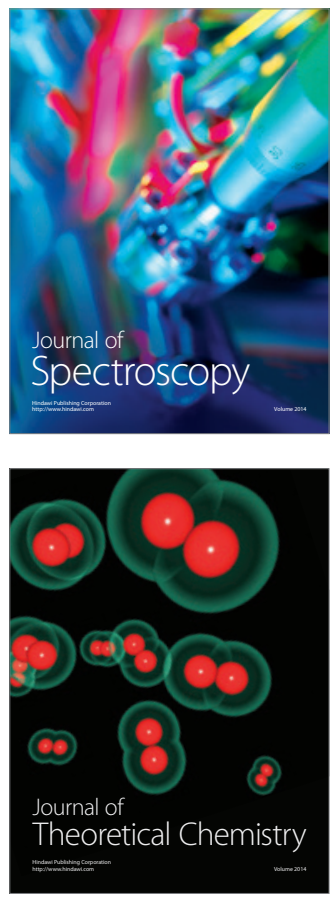
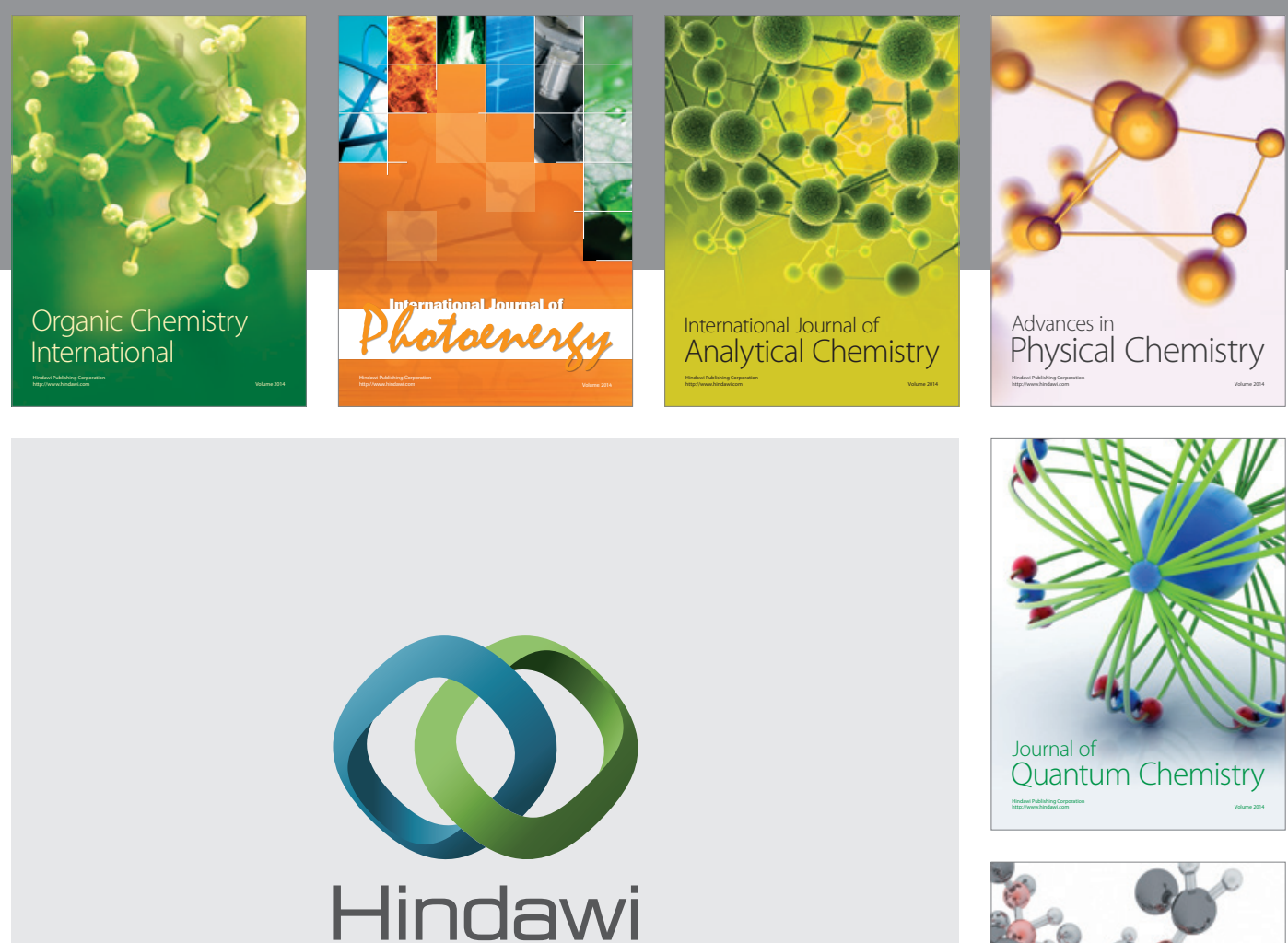

Submit your manuscripts at

http://www.hindawi.com

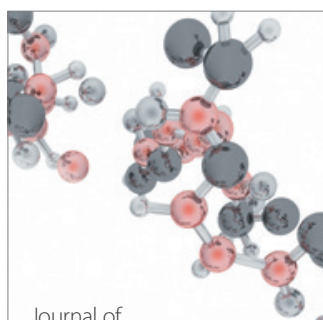

Analytical Methods

in Chemistry

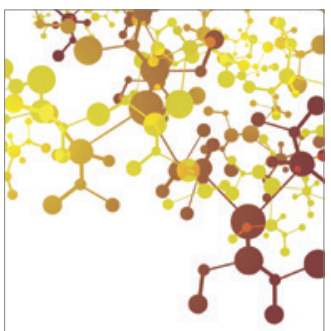

Journal of

Applied Chemistry

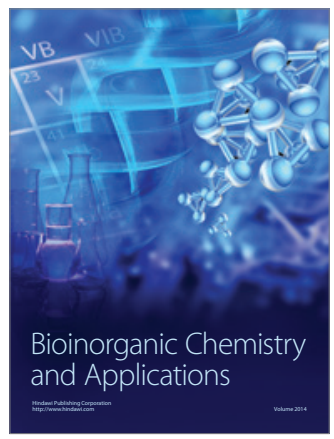

Inorganic Chemistry
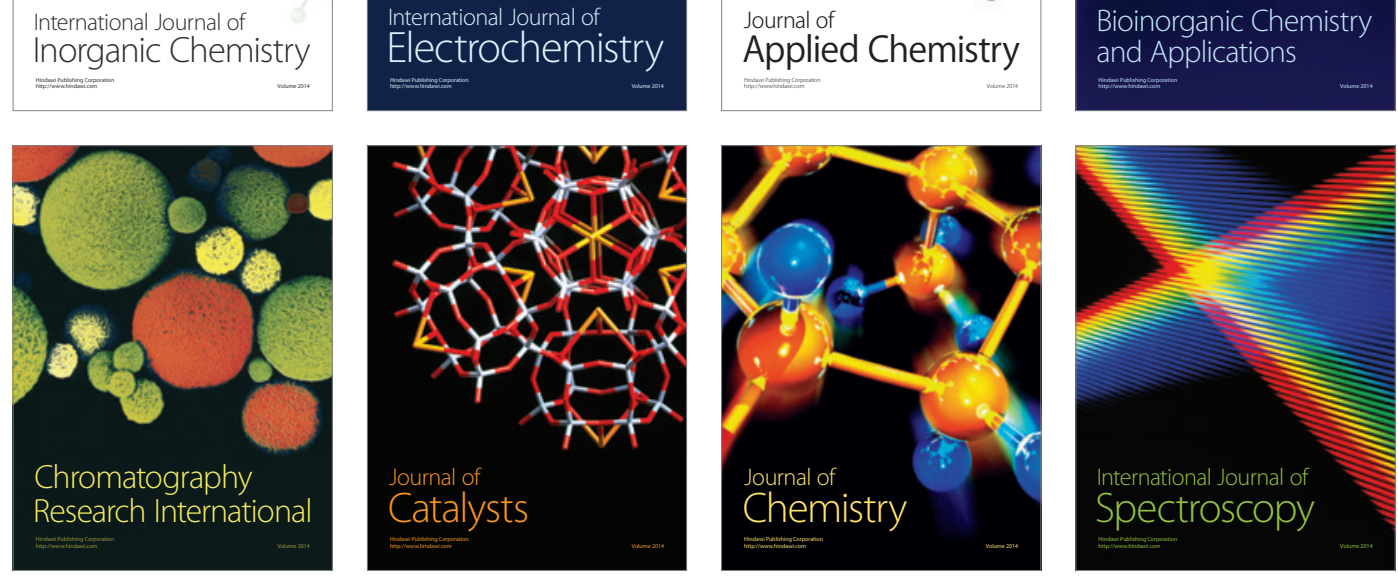